\title{
Colorado air quality impacted by long-range-transported aerosol: a set of case studies during the 2015 Pacific Northwest fires
}

\author{
Jessie M. Creamean ${ }^{1,2}$, Paul J. Neiman ${ }^{2}$, Timothy Coleman ${ }^{1,2}$, Christoph J. Senff ${ }^{1,3}$, Guillaume Kirgis ${ }^{1,3}$, \\ Raul J. Alvarez ${ }^{3}$, and Atsushi Yamamoto ${ }^{4}$ \\ ${ }^{1}$ University of Colorado at Boulder, Cooperative Institute for Research in Environmental Sciences, Boulder, CO 80309, USA \\ ${ }^{2}$ NOAA Earth System Research Laboratory, Physical Sciences Division, Boulder, CO 80305, USA \\ ${ }^{3}$ NOAA Earth System Research Laboratory, Chemical Sciences Division, Boulder, CO 80305, USA \\ ${ }^{4}$ HORIBA Instruments Inc., Process and Environmental, Irvine, CA 92618, USA \\ Correspondence to: Jessie M. Creamean (jessie.creamean@noaa.gov)
}

Received: 6 April 2016 - Published in Atmos. Chem. Phys. Discuss.: 2 May 2016

Revised: 15 August 2016 - Accepted: 11 September 2016 - Published: 29 September 2016

\begin{abstract}
Biomass burning plumes containing aerosols from forest fires can be transported long distances, which can ultimately impact climate and air quality in regions far from the source. Interestingly, these fires can inject aerosols other than smoke into the atmosphere, which very few studies have evidenced. Here, we demonstrate a set of case studies of long-range transport of mineral dust aerosols in addition to smoke from numerous fires (including predominantly forest fires and a few grass/shrub fires) in the Pacific Northwest to Colorado, US. These aerosols were detected in Boulder, Colorado, along the Front Range using beta-ray attenuation and energy-dispersive X-ray fluorescence spectroscopy, and corroborated with satellite-borne lidar observations of smoke and dust. Further, we examined the transport pathways of these aerosols using air mass trajectory analysis and regionaland synoptic-scale meteorological dynamics. Three separate events with poor air quality and increased mass concentrations of metals from biomass burning ( $\mathrm{S}$ and $\mathrm{K}$ ) and minerals $(\mathrm{Al}, \mathrm{Si}, \mathrm{Ca}, \mathrm{Fe}$, and $\mathrm{Ti}$ ) occurred due to the introduction of smoke and dust from regional- and synoptic-scale winds. Cleaner time periods with good air quality and lesser concentrations of biomass burning and mineral metals between the haze events were due to the advection of smoke and dust away from the region. Dust and smoke present in biomass burning haze can have diverse impacts on visibility, health, cloud formation, and surface radiation. Thus, it is important to understand how aerosol populations can be influenced by long-range-transported aerosols, particularly those emitted from large source contributors such as wildfires.
\end{abstract}

\section{Introduction}

Wildfires in both forested and agricultural regions serve as a steady source of pollutants into the atmosphere. Gas phase constituents such as methane $\left(\mathrm{CH}_{4}\right)$, carbon monoxide $(\mathrm{CO})$, carbon dioxide $\left(\mathrm{CO}_{2}\right)$, sulphur dioxide $\left(\mathrm{SO}_{2}\right)$, and nitrogen oxides $\left(\mathrm{NO}_{x} ; \mathrm{NO}+\mathrm{NO}_{2}\right)$ can be produced from burning of biofuels (Gadi et al., 2003; Radojevic, 2003), in addition to precursors that induce ozone production (Jaffe and Wigder, 2012). Additionally, wildfires produce large concentrations of aerosols which are injected into the atmosphere or formed in the smoke plume via secondary processes and include carbonaceous species (elemental and organic carbon) (Park et al., 2003; Spracklen et al., 2007) and biogenic heavy metals (including but not limited to $\mathrm{Fe}, \mathrm{Mn}, \mathrm{Cd}, \mathrm{Cu}, \mathrm{Pb}, \mathrm{Cr}$, and $\mathrm{Ni}$ ) (Nriagu, 1989; Radojevic, 2003). Soluble inorganic species such as sulphate, nitrate, ammonium, and chloride are found in fire emissions and partitioned to the particle phase through heterogeneous reactions with the gas phase species released during the combustion process (Pio et al., 2008). Strong, turbulent winds inside combustion zones from controlled and wild vegetation fires can introduce considerable amounts of dust particles into the free troposphere, which can subsequently be transported over thousands of kilometers with the smoke (Clements et al., 2008; Ansmann et al., 2009; Baars et al., 2011). Forest fires tend to be much larger than agricultural fires and enable injection of smoke high into the free troposphere (Colarco et al., 2004; Peterson et al., 2014). Yet smoke from agricultural and shrub- and grassland fires 
can still be transported long distances. However, few studies have documented how wildfires from any of the aforementioned biofuel sources inject mineral dust into the atmosphere (Gaudichet et al., 1995; Chalbot et al., 2013; Yang et al., 2013; Nisantzi et al., 2014), particularly in heavily forested or agricultural regions such as the Pacific Northwest of the US where dust sources are limited relative to arid regions in Africa, the Middle East, and Asia. Prescribed burning (i.e., slash-and-burn techniques) and wildfires are common in these arid "dust belt" regions, inducing the simultaneous emission of dust and smoke (Streets et al., 2003; Pinker et al., 2010).

Aerosols produced directly from wildfires (i.e., carbonaceous and soluble inorganic particulates) or injected into the free troposphere from smoke plume dynamics (i.e., mineral dust) have diverse effects on climate and air quality. For instance, absorbing aerosols such as soot from fires enhance the semi-direct effect that affect cloud and atmospheric lapse rate, particularly when the absorbing aerosols are above cloud (Ge et al., 2014). Further, hygroscopic organic aerosol, sulphate, and nitrate can enable aerosols to serve as cloud condensation nuclei (CCN) (Cruz and Pandis, 1997), whereas mineral dust and black carbon are effective ice-nucleating particles (INPs) at sub-freezing temperatures (DeMott et al., 1999, 2003; Vali et al., 2015). Both of these aerosol nuclei modify cloud radiative properties and lifetime, impact precipitation formation, and have been shown to originate from prescribed burns and wildfires (Eagan et al., 1974; McCluskey et al., 2014). Enhanced pollutants from fires also severely influence air quality and can prompt adverse health effects (Bravo et al., 2002; Phuleria et al., 2005; Wiedinmyer et al., 2006). For instance, smoke plumes from wildfires have been linked to childhood mortality (Jayachandran, 2008), asthma (Bowman and Johnston, 2005), and various respiratory illness and diseases (Mott et al., 2002; Moore et al., 2006). These effects are additionally complicated by aging from biogenic gases in the smoke plume during transport. Further, previous air quality studies on the east coast of the US have shown that enhanced aerosol optical depths (AODs) associated with both wildfires and anthropogenic sources can cause large errors in meteorological models used to forecast poor-air-quality events (Zamora et al., 2005). Overall, the aerosol species emitted or formed from wildfire plumes are complex in nature and possess several diverse climate and health effects, thus demonstrating the need to better understand the various types, sources, and transport pathways of these emissions.

Air quality is strongly dependent not only on emission sources such as wildfires but also on weather and climate change (Jacob and Winner, 2009). Regions with complex topography such as the Front Range of Colorado, US (see Fig. 1), have unique meteorological phenomena such as upslope/downslope flows that serve as agents for focusing or cleaning out local air pollution from the Denver metropolitan area (Haagenson, 1979). Typically, this region is char-

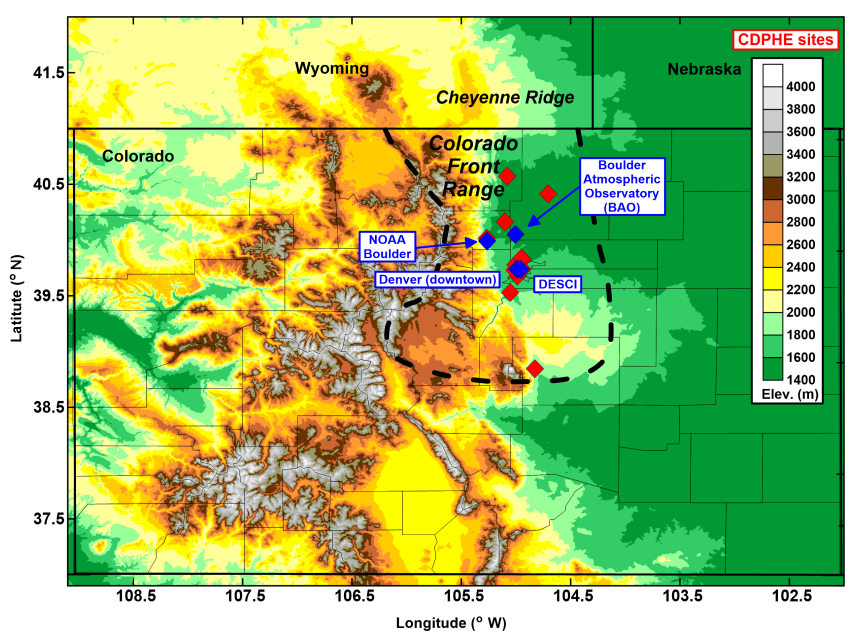

Figure 1. Map of monitoring locations, including NOAA DSRC in Boulder, which housed the PX-375 and TOPAZ lidar instruments; the BAO, where the $449 \mathrm{MHz}$ wind profiler was deployed; downtown Denver; the CDPHE DESCI site, where atmospheric extinction/visibility is measured; and the CDPHE sites where $\mathrm{PM}_{2.5}$ and $\mathrm{PM}_{10}$ are monitored (see Table 1 for site descriptions). The approximate area encompassing the Colorado Front Range is highlighted by the dashed line. The Cheyenne Ridge in Wyoming is also notated.

acterized by good air quality in terms of particulate matter (PM) relative to other larger urban and industrial areas, although it experiences occasional pollution episodes due to modulation of the mountain slope dynamics, oil and natural gas production, and wildfires (Watson et al., 1998; Sibold and Veblen, 2006; Brown et al., 2013). Here, we show that the Front Range air quality was severely impacted by longrange-transported wildfire emissions from the Pacific Northwest during August 2015. A reoccurring influx of smoke aerosols infiltrated the Front Range region due to shifts in regional- and synoptic-scale meteorology. Interestingly, mineral dust was also transported with the smoke plume to the Front Range from the wildfires. This complex mixture of aerosols can have numerous climate and health effects in the region and should be evaluated to develop a better understanding of future influences from wildfire emissions, especially considering a warmer and drier climate will potentially lead to more frequent wildfires (Westerling et al., 2006; Liu et al., 2010).

\section{Methods}

\subsection{Satellite observations}

The source of aerosols from the fires was determined using imagery from the Moderate Resolution Imaging Spectroradiometer (MODIS) on board the Terra satellite. MODIS is a multi-spectral sensor with 36 spectral bands, ranging 
Table 1. CDPHE sites used for particulate data within the Colorado Front Range. Each site has an " $\times$ " for each measurement it maintained throughout the current work. Elevation is provided in meters above mean sea level (m a.m.s.l.).

\begin{tabular}{llccccc}
\hline City/site name & Site ID & $\begin{array}{c}\text { Latitude } \\
\left({ }^{\circ} \mathrm{N}\right)\end{array}$ & $\begin{array}{c}\text { Longitude } \\
\left({ }^{\circ} \mathrm{W}\right)\end{array}$ & $\begin{array}{c}\text { Elevation } \\
(\mathrm{m} \text { a.m.s.1. })\end{array}$ & $\mathrm{PM}_{2.5}$ & $\mathrm{PM}_{10}$ \\
\hline Boulder - CU/Athens & BOU & 40.01 & 105.27 & 1621 & $\times$ & \\
Chatfield Park & CHAT & 39.53 & 105.05 & 1685 & $\times$ & \\
Colorado College & CCOL & 38.85 & 104.83 & 1833 & $\times$ & \\
Commerce City/Alsup Elementary & COMM & 39.83 & 104.94 & 1565 & $\times$ & \\
Denver - continuous air monitoring site & CAMP & 39.68 & 104.99 & 1610 & $\times$ & $\times$ \\
Denver - National Jewish Health & NJH & 39.74 & 104.94 & 1615 & $\times$ & \\
Fort Collins - CSU facilities & FTCF & 40.57 & 105.08 & 1525 & $\times$ & $\times$ \\
Greeley - hospital & GREH & 40.42 & 104.71 & 1439 & $\times$ & \\
I-25-Denver & I-25 & 39.73 & 105.02 & 1586 & $\times$ & $\times$ \\
La Casa & CASA & 39.78 & 105.01 & 1601 & $\times$ & $\times$ \\
Longmont - municipal & LNGM & 40.16 & 105.10 & 1517 & $\times$ & $\times$ \\
Welby & WBY & 39.84 & 104.95 & 1554 & & $\times$ \\
\hline
\end{tabular}

$\mathrm{PM}_{2.5}$ : particulate matter with diameters $\leq 2.5 \mu \mathrm{m} . \mathrm{PM}_{10}$ : particulate matter with diameters $\leq 10 \mu \mathrm{m}$.

in wavelength from 0.4 to $14.2 \mu \mathrm{m}$. AOD data at $550 \mathrm{~nm}$ from MODIS were acquired from the Giovanni data server (http://giovanni.gsfc.nasa.gov/giovanni/) for daily AOD at a $1^{\circ}$ spatial resolution using a domain of 82 to $163^{\circ} \mathrm{W}$ and 26 to $59^{\circ} \mathrm{N}$ (MOD08_D3_051). MODIS AOD is retrieved from three spectral channels $(0.47 \mu \mathrm{m}, 0.66$, and $2.1 \mu \mathrm{m})$ using the algorithm described by Kaufman et al. (1997) in cloud-free pixels $(10 \mathrm{~km} \times 10 \mathrm{~km}$ grid box) (Ackerman et al., 1998). Fire and surface thermal anomaly data were also acquired from the MODIS Terra satellite using brightness temperature measurements in the 4 and $11 \mu \mathrm{m}$ channels (https://earthdata.nasa.gov/labs/worldview/) (Giglio, 2010). The fire detection strategy is based on absolute detection of a fire (when the fire strength is sufficient to detect) and on detection relative to its background (to account for variability of the surface temperature and reflection by sunlight) (Giglio et al., 2003). The algorithms include masking of clouds, bright surfaces, glint, and other potential false alarms (Giglio et al., 2003). Swaths from overpasses over the Pacific Northwest were used to determine the locations of fires on a daily basis.

In order to evaluate the types of aerosols present in enhanced AOD plumes over the western US, aerosol subtype data were retrieved from Cloud-Aerosol Lidar with Orthogonal Polarization (CALIOP) on board Cloud-Aerosol Lidar and Infrared Pathfinder Satellite Observations (CALIPSO). Level-2 ValStage1 V.30 Vertical Feature Mask data obtained from NASA's Earth Observing System Data and Information System (EOSDIS; https://search.earthdata.nasa.gov/) contain vertically resolved data of aerosol layer subtype, including but not limited to smoke, dust, and polluted dust (i.e., dust mixed with smoke) (Vaughan et al., 2004; Omar et al., 2009; Winker et al., 2009). CALIPSO was launched on 28 April 2006 and flies at an orbital altitude of $705 \mathrm{~km}$ as part of the sun-synchronous "A-train" satellite constellation. CALIOP is an elastic backscatter lidar operating at 532 and
$1064 \mathrm{~nm}$, completed with a depolarization channel at $532 \mathrm{~nm}$ to enable detection of aerosols and clouds. Granule data were acquired from orbital swaths that passed over the northwestern US (domain includes Washington, Oregon, northern California, Idaho, Nevada, Montana, Wyoming, Utah, and Colorado) from 15 August to 2 September 2015 and processed using modified Python code developed by the Hierarchical Data Format (HDF) group at the University of Illinois, Urbana-Champaign (http://hdfeos.org/). Aerosol subtypes were also examined off the US west coast across the central North Pacific Ocean, in the context of air mass trajectory analysis, to ensure mineral dust and smoke were transported to Colorado from the Pacific Northwest fires rather than from deserts or fires overseas.

\subsection{Colorado air quality data}

All air quality data were acquired from the Colorado Department of Public Health and Environment (CDPHE; http: //www.colorado.gov/airquality/report.aspx) from 15 August to 2 September 2015 at various sites throughout the Colorado Front Range (see Fig. 1). The DESCI site (Denver Visibility Station; $39.73^{\circ} \mathrm{N}, 104.96^{\circ} \mathrm{W} ; 1633 \mathrm{~m}$ a.m.s.l.) is highlighted in blue, near downtown Denver, where horizontal atmospheric extinction $\left(\mathrm{km}^{-1}\right)$ data measured with a transmissometer are available through CDPHE. These data provide a quantitative measure of "haziness" indicated throughout the text. Table 1 provides the site latitudes, longitudes, and elevations, as well as which PM measurements were available at each site. Hourly measurements included mass concentrations $\left(\mu \mathrm{g} \mathrm{m}^{-3}\right)$ of particulate matter for particles with diameters $\leq 2.5 \mu \mathrm{m}\left(\mathrm{PM}_{2.5}\right)$ and $\leq 10 \mu \mathrm{m}\left(\mathrm{PM}_{10}\right)$. All times shown are coordinated universal time (UTC; local time or mountain daylight time (MDT) +6). 


\subsection{In situ aerosol observations at Boulder, Colorado}

Real-time, hourly ambient aerosol samples were analyzed for $\mathrm{PM}_{2.5}$ mass concentrations $\left(\mu \mathrm{g} \mathrm{m}^{-3}\right)$ and concentrations of various metals $\left(\mathrm{ng} \mathrm{m}^{-3}\right)$ using the HORIBA, Ltd. PX-375 continuous particle mass and elemental speciation monitor (http://www.horiba.com/processenvironmental/products/ambient/details) from 26 August to 2 September 2015 at the National Oceanic and Atmospheric Administration (NOAA) David Skaggs Research Center (DSRC) located in Boulder, Colorado $\left(39.99^{\circ} \mathrm{N}, 105.26^{\circ} \mathrm{W}\right.$, and $1672 \mathrm{~m}$ a.m.s.l.; see Fig. 1). The PX-375 draws in air at $16.7 \mathrm{~L} \mathrm{~min}^{-1}$ through a US Environmental Protection Agency (EPA) louvered $\mathrm{PM}_{10}$ inlet and subsequently passes through a BGI Very Sharp Cut Cyclone $\left(\right.$ VSCC $^{\mathrm{TM}}$ ) to filter for particles smaller than $2.5 \mu \mathrm{m}$ in diameter. Air is pulled through a nozzle for $60 \mathrm{~min}$ per hourly sample, where particles are subsequently deposited in a $100 \mathrm{~mm}$ diameter spot on Teflon $^{\mathrm{TM}}$ polytetrafluoroethylene (PTFE) fabric filter tape for analysis. Once the sample is collected for $60 \mathrm{~min}$, beta-ray attenuation and energy-dispersive X-ray fluorescence spectroscopy (EDXRF) analyses are conducted for $60 \mathrm{~min}$ and $1000 \mathrm{~s}$, respectively, per hourly sample, simultaneous to the collection of the subsequent sample. Beta-ray attenuation analysis is used to measure total $\mathrm{PM}_{2.5}$ mass concentrations, and EDXRF is used to analyze concentrations of $\mathrm{Ti}, \mathrm{V}, \mathrm{Cr}$, $\mathrm{Mn}, \mathrm{Fe}, \mathrm{Ni}, \mathrm{Cu}, \mathrm{Zn}, \mathrm{As}, \mathrm{Pb}, \mathrm{Al}, \mathrm{Si}, \mathrm{S}, \mathrm{K}$, and $\mathrm{Ca}$. The EDXRF unit contains a complementary metal-oxide-semiconductor (CMOS) camera for sample images. The calibration material used for X-ray intensity is National Institute of Standards and Technology (NIST) Standard Reference Materials (SRM) 2783. Lower detection limits (LDLs) are shown in Table 2 , and error was calculated to be $\pm 2 \%$ for hourly metal concentrations. Hourly total $\mathrm{PM}_{2.5}$ mass concentrations had an LDL of $2.00 \mathrm{\mu g} \mathrm{m}^{-3}$.

\subsection{Aerosol and ozone remote-sensing observations at Boulder, Colorado}

The Tunable Optical Profiler for Aerosol and oZone (TOPAZ) lidar was operated at the DSRC on 9 days from 14 August through 2 September 2015, and it collected about $62 \mathrm{~h}$ of ozone and aerosol profile data, primarily between mid-morning and early evening local time. TOPAZ is a stateof-the-art, tunable ozone differential absorption lidar. It emits pulsed laser light at three ultraviolet wavelengths between 285 and $295 \mathrm{~nm}$ and measures ozone as well as aerosol backscatter and extinction profiles with high temporal and spatial resolutions (Alvarez et al., 2011). The TOPAZ lidar is mounted in a truck with a rooftop two-axis scanner. This scanner permits pointing the lidar beam at elevation angles between -5 and $30^{\circ}$ at a fixed but changeable azimuth angle. To achieve zenith operation, the scanner mirror is moved out of the beam path. Typical TOPAZ operation consists of a scan sequence at $2,6,20$, and $90^{\circ}$ elevation, repeated approx-
Table 2. Lower detection limits (LDLs, $\mathrm{ng} \mathrm{m}^{-3}$ ) for metals measured by the PX-375 during 26 August-2 September 2015. Concentrations less than the LDLs were excluded from analysis.

\begin{tabular}{ll}
\hline Species & LDL \\
\hline $\mathrm{Ti}$ & 2.29 \\
$\mathrm{~V}$ & 0.23 \\
$\mathrm{Cr}$ & 0.61 \\
$\mathrm{Mn}$ & 0.93 \\
$\mathrm{Fe}$ & 1.51 \\
$\mathrm{Ni}$ & 0.33 \\
$\mathrm{Cu}$ & 0.78 \\
$\mathrm{Zn}$ & 1.21 \\
$\mathrm{As}$ & 0.02 \\
$\mathrm{~Pb}$ & 0.80 \\
$\mathrm{Al}$ & 32.2 \\
$\mathrm{Si}$ & 5.17 \\
$\mathrm{~S}$ & 1.11 \\
$\mathrm{~K}$ & 4.37 \\
$\mathrm{Ca}$ & 1.18 \\
\hline
\end{tabular}

imately every $5 \mathrm{~min}$. The range-resolved ozone and aerosol observations at the shallow elevations angles are projected onto the vertical and spliced together with the zenith observations, resulting in composite vertical ozone and aerosol profiles from about $15 \mathrm{~m}$ to $2-3 \mathrm{~km}$ above ground level (a.g.l.) at 5 min time resolution (Alvarez et al., 2012). In this study, we only used the lidar aerosol extinction profiles measured at a wavelength of $294 \mathrm{~nm}$. The aerosol profile retrieval requires assumptions about the lidar calibration constant and the aerosol extinction-to-backscatter or lidar ratio. For this study we used an altitude-constant lidar ratio of $40 \mathrm{sr}$, which is a good approximation for continental and urban aerosols. The lidar signal at the aerosol wavelength of $294 \mathrm{~nm}$ is also affected by ozone absorption. Therefore, uncertainties in the ozone observations can cause biases in the aerosol retrieval. This, combined with uncertainties in the calibration constant and lidar ratio, can lead to errors in the aerosol extinction coefficient profiles of up to about $30 \%$. The precision of the $5 \mathrm{~min}$ aerosol extinction measurements is typically better than $10 \%$.

\subsection{Meteorological data and analysis}

A gridded perspective of synoptic-scale conditions across North America was provided using the NOAA/National Centers for Environmental Prediction (NCEP) Rapid Refresh numerical data package (RAP; http://rapidrefresh.noaa.gov/; Benjamin et al., 2016). The RAP is an operational assimilation/modeling system updated hourly, with $13 \mathrm{~km}$ horizontal resolution and 50 vertical levels.

Air mass backward trajectory analyses were conducted using HYSPLIT 4 (HYbrid Single-Particle Lagrangian Integrated Trajectory; Draxler and Rolph, 2011) and data from 

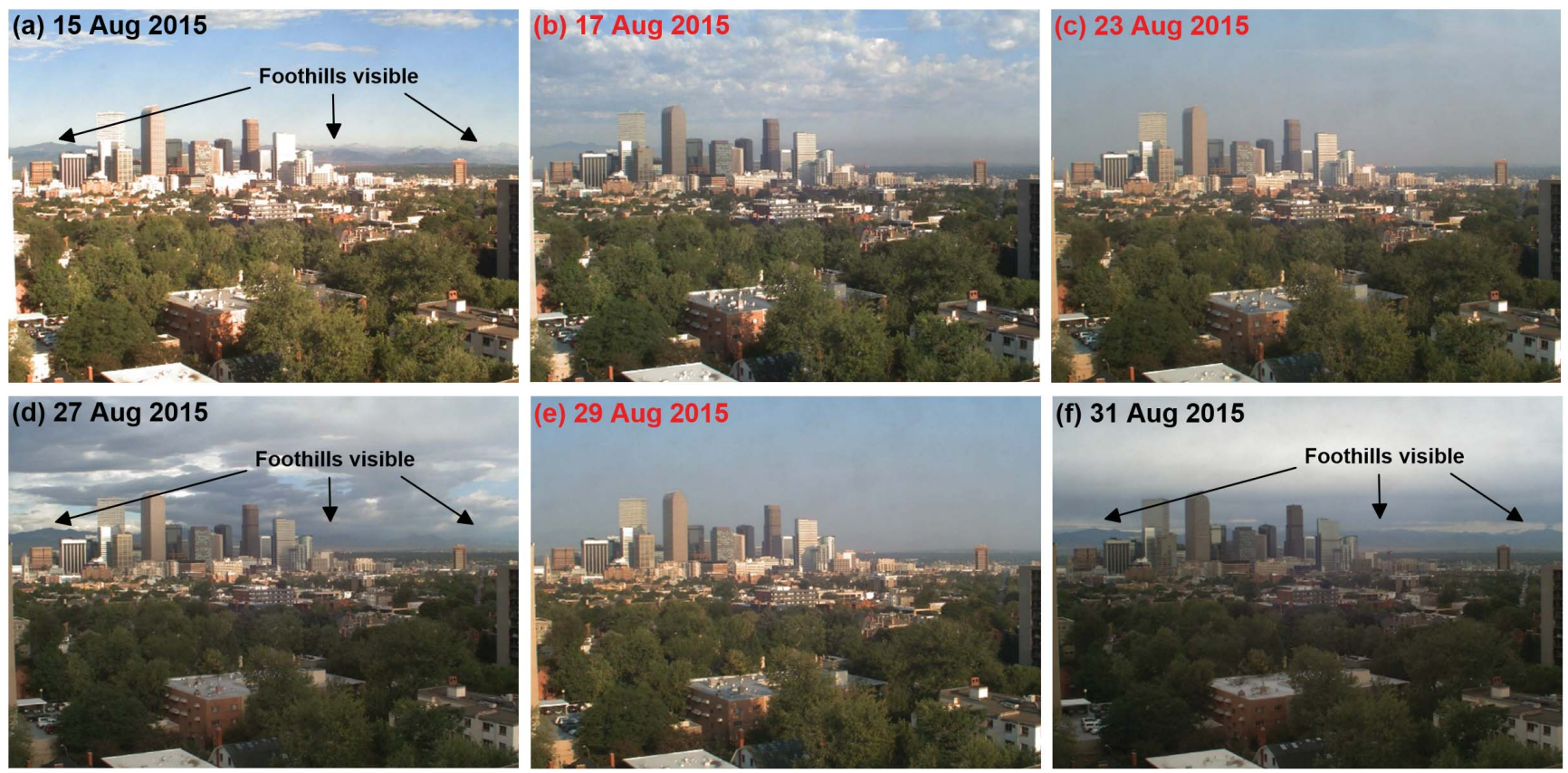

Figure 2. Images of downtown Denver facing west taken at 14:00 UTC (08:00 MDT). Images acquired from the CDPHE Visibility Station (DESCI; $39.73^{\circ} \mathrm{N}, 104.96^{\circ} \mathrm{W} ; 1633 \mathrm{~m}$ a.m.s.l.). Only days of significant meteorological and visibility transitions in August 2015 are shown. Days in red are those which correspond to the haziest days during the study time period. In panels (a), (d), and (f), the visibility of the foothills (and background high terrain) is highlighted.

the NOAA/NCEP Global Data Assimilation System (GDAS) (Kalnay et al., 1996). HYSPLIT trajectories do not include processes that may affect particle concentrations such as convective transport, wet removal, or dry removal, and they are only intended to highlight the possible transport pathways. To study the potential for transport from the Pacific Northwest fires region, and to eliminate potential contribution from aerosol sources overseas, we used an ensemble of backward trajectories initiated at multiple altitudes and times ending above the NOAA building in Boulder. Ten-day back trajectories were initiated every $6 \mathrm{~h}$ (at 00:00, 06:00, 12:00, and 18:00 UTC) during 15 August-2 September 2015 at 500, 1000 , and $2000 \mathrm{~m}$ a.g.l. (corresponding to 2172,2672 , and $3672 \mathrm{~m}$ a.m.s.1.).

A $449 \mathrm{MHz}$ wind profiler (White et al., 2013) - deployed near the Boulder Atmospheric Observatory in Erie, Colorado (BAO; $40.05^{\circ} \mathrm{N}, 105.01^{\circ} \mathrm{W}$, and $1577 \mathrm{~m}$ a.m.s.l.; location shown in Fig. 1) - provided hourly-averaged profiles of horizontal wind. The high (low) mode extended from $145 \mathrm{~m}$ $(195 \mathrm{~m})$ to $10074 \mathrm{~m}(5059 \mathrm{~m})$ a.g.l. with a vertical resolution of $200 \mathrm{~m}(100 \mathrm{~m})$. The wind-profiler data were edited objectively using the vertical-temporal continuity method of Weber et al. (1993) and then subjected to additional manual editing as needed. For the purpose of this study, we utilized only the low-mode observations.

\section{Results and discussion}

\subsection{Haze events induced poor air quality along Colorado's Front Range}

The shift in air quality was evident during three August haze events in the Denver metro area. Figure 2 shows photos of notable air quality transitions in Denver looking westward towards the foothills of the Rocky Mountains, and Fig. 3 shows the atmospheric extinction measurements from DESCI. Higher values of extinction indicate hazier conditions. The image on 15 August shows typical clean conditions, where the foothills were visible west of Denver. Extinction was also relatively low on 15 August. On 17 August, a haze settled in the region, creating a low-level pollution plume that masked the view of the foothills. This haze continued to infiltrate the Denver metro area, reaching the poorest visibility (i.e., highest extinction) on 23 August. This haze persisted in the Denver metro area until 27 August, when clear conditions were re-established and the foothills were once again visible. However, the air quality deteriorated again by 29 August, with hazy conditions obscuring the foothills. This haze event was shorter lived, clearing out on 31 August. The cleaner conditions persisted until the end of the measurement period on 2 September. The qualitative observations of the three separate haze events were corroborated by in situ air quality measurements along the Front Range. Figure 3 also shows hourly and daily averaged $\mathrm{PM}_{2.5}$ mass concentrations 


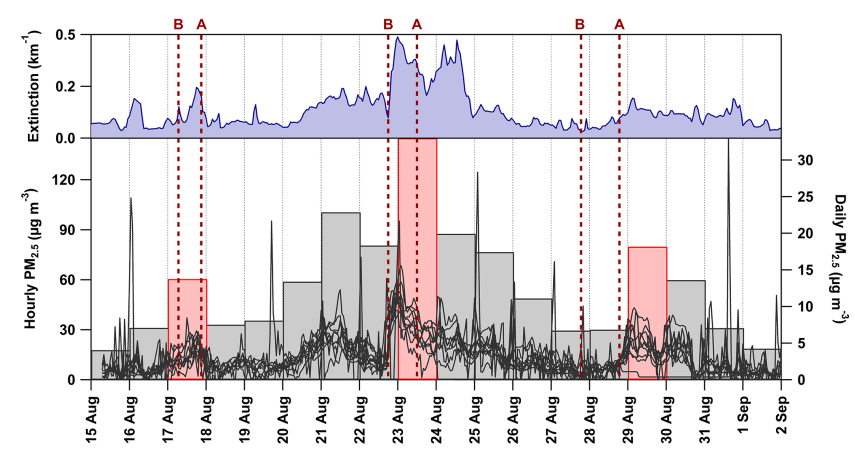

Figure 3. Top panel shows atmospheric extinction measured at the CDPHE DESCI site (see Fig. 1). Bottom panel shows hourly and daily averaged $\mathrm{PM}_{2.5}$ mass concentrations at CDPHE sites. The pairs of red dashed lines shows the times before ("B") and after ("A") cold-frontal passages at BAO during or prior to each haze event. The daily averaged $\mathrm{PM}_{2.5}$ in red represents the haziest days during or following cold-frontal passages (i.e., events 1, 2, and 3 on 17, 23, and 29 August 2015, respectively).

(herein simply called " $\mathrm{PM}_{2.5}$ ") at the sites provided in Table 1. Overall, three separate haze events occurred along the Front Range with the worst days visually observed (Fig. 2) on 17, 23, and 29 August (events 1, 2, and 3, respectively), when extinction was highest, $\mathrm{PM}_{2.5}$ reached maximum concentrations, and a cold front passed through (discussed in Sect. 3.3). Prior to each of these events, $\mathrm{PM}_{2.5}$ was suppressed and then slowly increased to each event's maximum concentrations on 17, 23, and 29 August. $\mathrm{PM}_{2.5}$ slowly decreased following each of these haze events. $\mathrm{PM}_{10}$ (not shown) did not follow similar increases and decreases to the $\mathrm{PM}_{2.5}$, suggesting the smaller particles contributing to $\mathrm{PM}_{2.5}$ originated from different, likely more distant sources as compared to coarser particles contributing to the $\mathrm{PM}_{10}$, which are likely from more local sources (VanCuren, 2003; Neff et al., 2008).

\subsection{Biomass burning plume propagates towards Colorado}

During the 15 August-2 September time period, fires in highelevation (>3000 fta.m.s.l.) forested areas and to some extent in shrub- and grasslands in the Pacific Northwest were prominent, while few fire hot spots were located in lowelevation agricultural land (see Fig. S1 in the Supplement). Figures 4-6 show MODIS retrievals of fire hot spots and AOD during the first, second, and third haze events in Colorado, when numerous fires were detected in Washington, Oregon, northern California, northern Idaho, and northwestern Montana. Three cases are defined as the time periods surrounding and including the haze event days: case 1 (15-18 August), case 2 (20-23 August), and case 3 (26-29 August).

On 15 August, prior to the onset of the first haze event in Colorado, the plume of enhanced AOD propagating from the fires in the Pacific Northwest remained north of Col- orado in Montana and southern Canada (Fig. 4). The air above the Denver-Boulder area contained relatively diminished AOD $\left(0.12\right.$, averaged from the domain of $39.5^{\circ} \mathrm{N}$, $104.5^{\circ} \mathrm{W}, 40.5^{\circ} \mathrm{N}$, and $105.5^{\circ} \mathrm{W}$ ). Although the core of the plume remained north of Colorado, its more diffuse southern region drifted southeastward on 16 August. By 17 August, enhanced AOD was observed along the Front Range in northcentral Colorado near Denver-Boulder (0.37). The AOD decreased slightly on 18 August over Denver-Boulder (0.25), which is supported by the decrease of $\mathrm{PM}_{2.5}$ starting on 18 August from the CDPHE data (Fig. 3). AOD increased in value and spatial extent on 20 August during the second haze event, when more fires were detected in the Pacific Northwest (see increase in number of MODIS hot spots in Fig. 5). This plume contained a high density of aerosols that traveled over the north-central US. The southern periphery of this plume impacted Colorado east of the Continental Divide starting on 20 August, as corroborated by the CDPHE air quality measurements in Fig. 3. Although the AOD values were not as enhanced over Colorado as compared to the core of the AOD plume, AOD values over the Front Range were enhanced as compared to before the long-range transport of this plume. Enhanced AOD was observed around Denver-Boulder and the Front Range the following 3 days $(0.26-0.35)$, with the largest values in this 4-day period observed on 23 August. The third haze event (Fig. 6) followed a similar evolution to the first two. The AOD plume remained north of Colorado on 26-27 August and then infiltrated the northern and eastern part of the state on 28-29 August. The AOD values over Denver-Boulder during this event (0.26-0.45) were considerably larger than the two previous events. It is important to note that AOD is a column measurement; thus the largest aerosol concentrations may be elevated in the atmosphere as compared to what is observed on the ground. However, the AOD observations still provide information regarding the spatial extent of the plume of aerosols emitted from the fires and show that Colorado was indeed impacted by air transported from the Pacific Northwest fires.

Further, the satellite retrievals generally corroborate the air quality observations on the ground along the Front Range in terms of when large concentrations of aerosols might be expected. More fires were detected across the Pacific Northwest by MODIS during the second event (678 fires, on average), when $\mathrm{PM}_{2.5}$ was largest, as compared to the first event (231 fires, on average), which had the smallest maximum $\mathrm{PM}_{2.5}$ out of the three haze events. The third event had $\mathrm{PM}_{2.5}$ values in between the first and second, while also having 607 fires on average. Thus, the number of fires likely influenced the relative amount of smoke produced and transported to the Front Range. However, meteorological conditions as described below also played a vital role in enabling transport of the smoke. 
(a) 15 Aug 2015
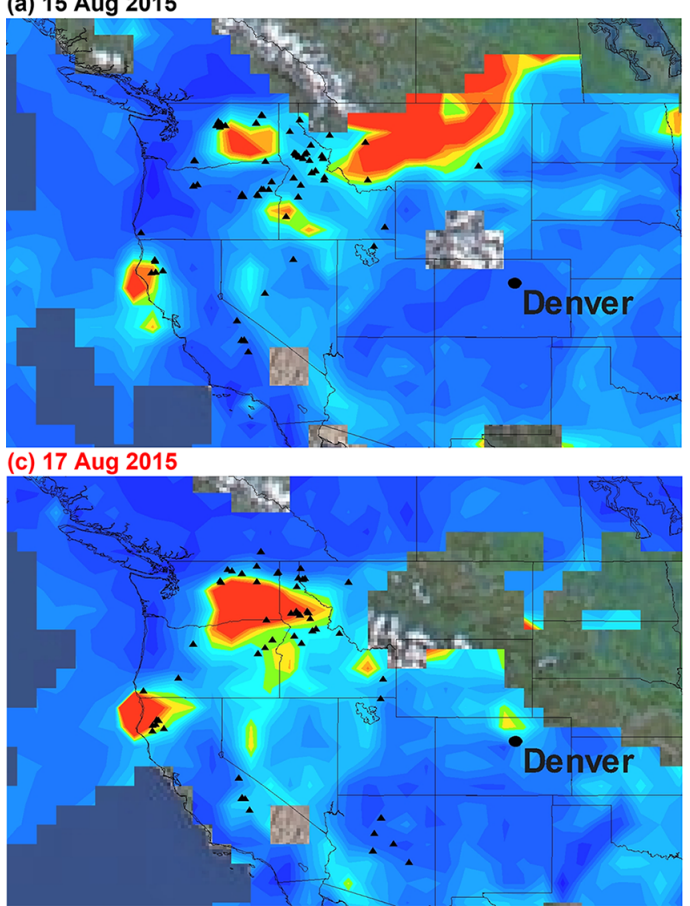

(b) 16 Aug 2015

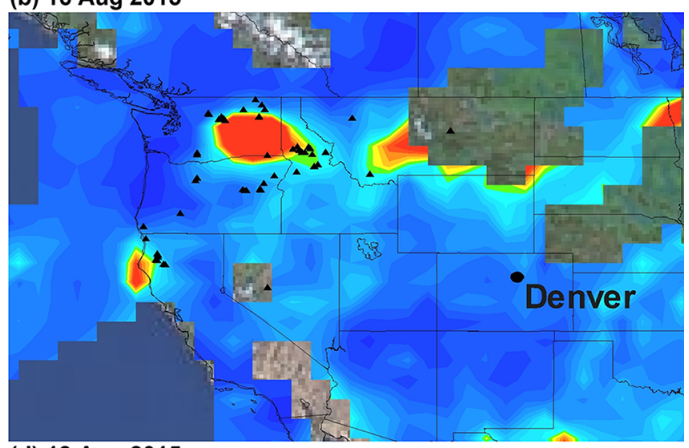

(d) 18 Aug 2015

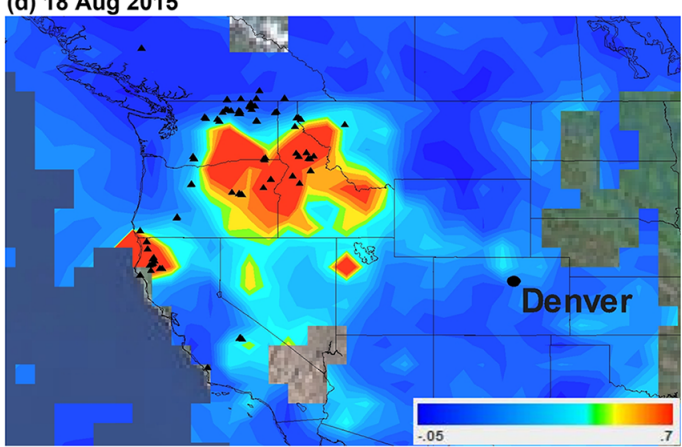

Figure 4. Daily averaged aerosol optical depth (AOD; color bar, lower right) at $550 \mathrm{~nm}$ and fire hot spots (black markers) detected by MODIS during the first major haze case study between 15 and 18 August 2015. The haziest day from the CDPHE data is labeled in red (i.e., event 1).

\section{(a) 20 Aug 2015}
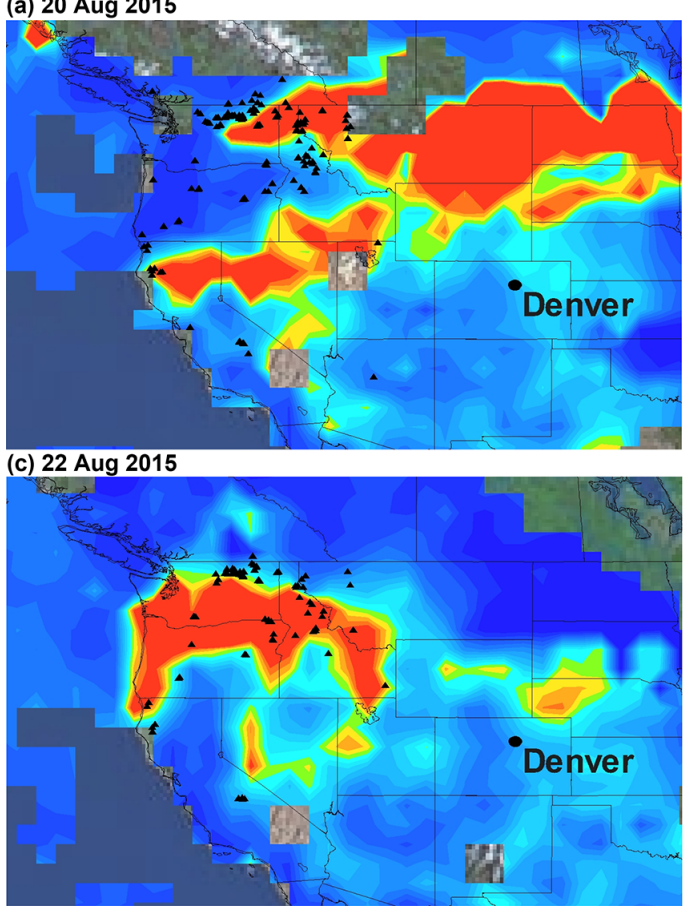

(b) 21 Aug 2015

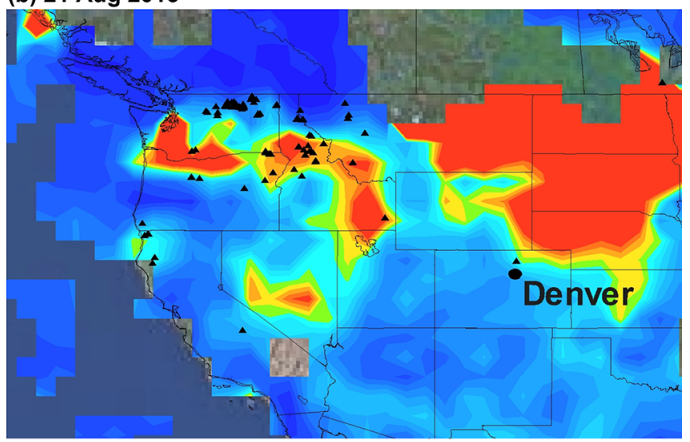

(d) 23 Aug 2015

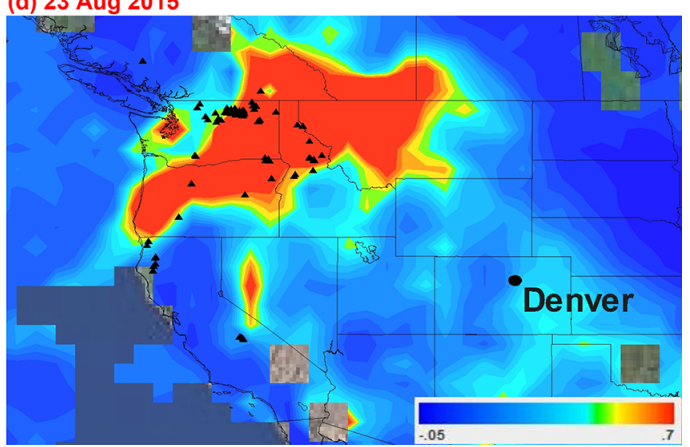

Figure 5. Same as Fig. 4 but for the second major haze event between 20 and 23 August 2015. The haziest day from the CDPHE data is labeled in red (i.e., event 2). 

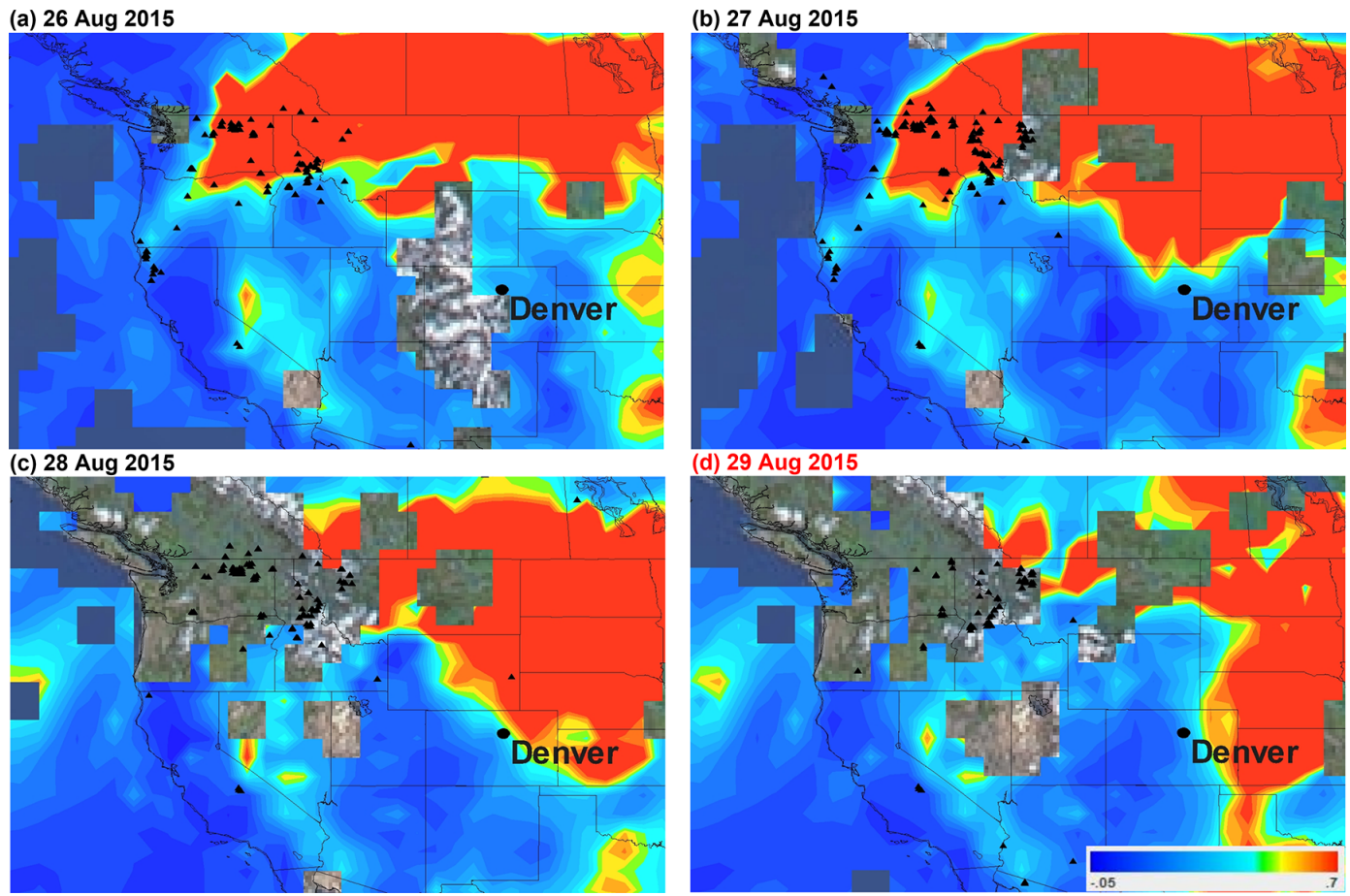

Figure 6. Same as Fig. 4 but for the third major haze event between 26 and 29 August 2015. The haziest day from the CDPHE data is labeled in red (i.e., event 3).

\subsection{Synoptic- and regional-scale meteorology fuel long-range aerosol transport from the Pacific Northwest}

The transport of the enhanced AOD plume from the Pacific Northwest to Colorado during each of the three events and the relationship between the AOD column and ground-based in situ observations are supported by the meteorological features present on both the synoptic and regional scales. Planview synoptic analyses aloft and at the surface during the first air quality event along Colorado's Front Range on 1718 August 2015 are shown in Fig. 7. At $500 \mathrm{hPa}$ (Fig. 7a and b), a transient shortwave trough embedded in baroclinic zonal flow aloft migrated eastward across the northern Rocky Mountains (i.e., north of Colorado), with westerly (northwesterly) flow preceding (following) the passage of the trough axis. These flow patterns are corroborated by the HYSPLIT air mass back trajectories during the first event, shown in Fig. 7e. On average, air mass back trajectories passed over the fire plume region $40 \%$ of the time; i.e., 19 of the 48 trajectories passed over regions of enhanced AOD and fire hot spot locations from MODIS. At the surface, high pressure and shallow cool air initially resided primarily north of Colorado at 06:00 UTC on 17 August (Fig. 7c). However, by 21:00 UTC on 17 August (Fig. 7d), the shallow cool air moved southward across eastern Colorado. A companion time-height section of hourly wind profiles at BAO (Fig. 7f) shows low-level southerly flow ahead of the frontal passage at $\sim$ 11:00 UTC on 17 August and generally westerly to northwesterly flow aloft for the duration of the plot. The observed flow aloft is represented in many of the back trajectories, which show west-to-northwest flow reaching Boulder during this event. Following the frontal passage at the wind profiler, the shallow cool air mass deepened to $\sim 3 \mathrm{~km}$ a.m.s.l. by 18:00 UTC on 17 August in generally northerly-component flow. Thereafter, the depth of the cool air decreased as the low-level flow shifted to southeasterly. Operational rawinsonde data from Denver (not shown) capture the top of the frontal inversion at $2.1 \mathrm{~km}$ a.m.s.l. at 12:00 UTC on 17 August and at $2.7 \mathrm{~km}$ a.m.s.l. at 00:00 UTC on 18 August, consistent with the wind-profiler analysis of the time-varying frontal altitude at BAO. For plan-view context, the times of the synoptic analyses are marked on the time-height section. The high $\mathrm{PM}_{2.5}$ values (Fig. 3) on 17 August are corroborated by the transition of air arriving from enhanced AOD regions (see air mass backward trajectories in Fig. 7e) over and off the coast of the Pacific Northwest and northern California (Fig. 4c). $\mathrm{PM}_{2.5}$ increased markedly after the passage of the shallow front, thus suggesting the postfrontal air mass - which originated over Wyoming downstream of the Pacific Northwest fires - contained a large concentration of particulates from those fires.

The evolution of the shallow cold front described above is typical of southward-propagating cold fronts more generally across eastern Colorado, and the frontal propagation is influenced heavily by the complex regional topography 

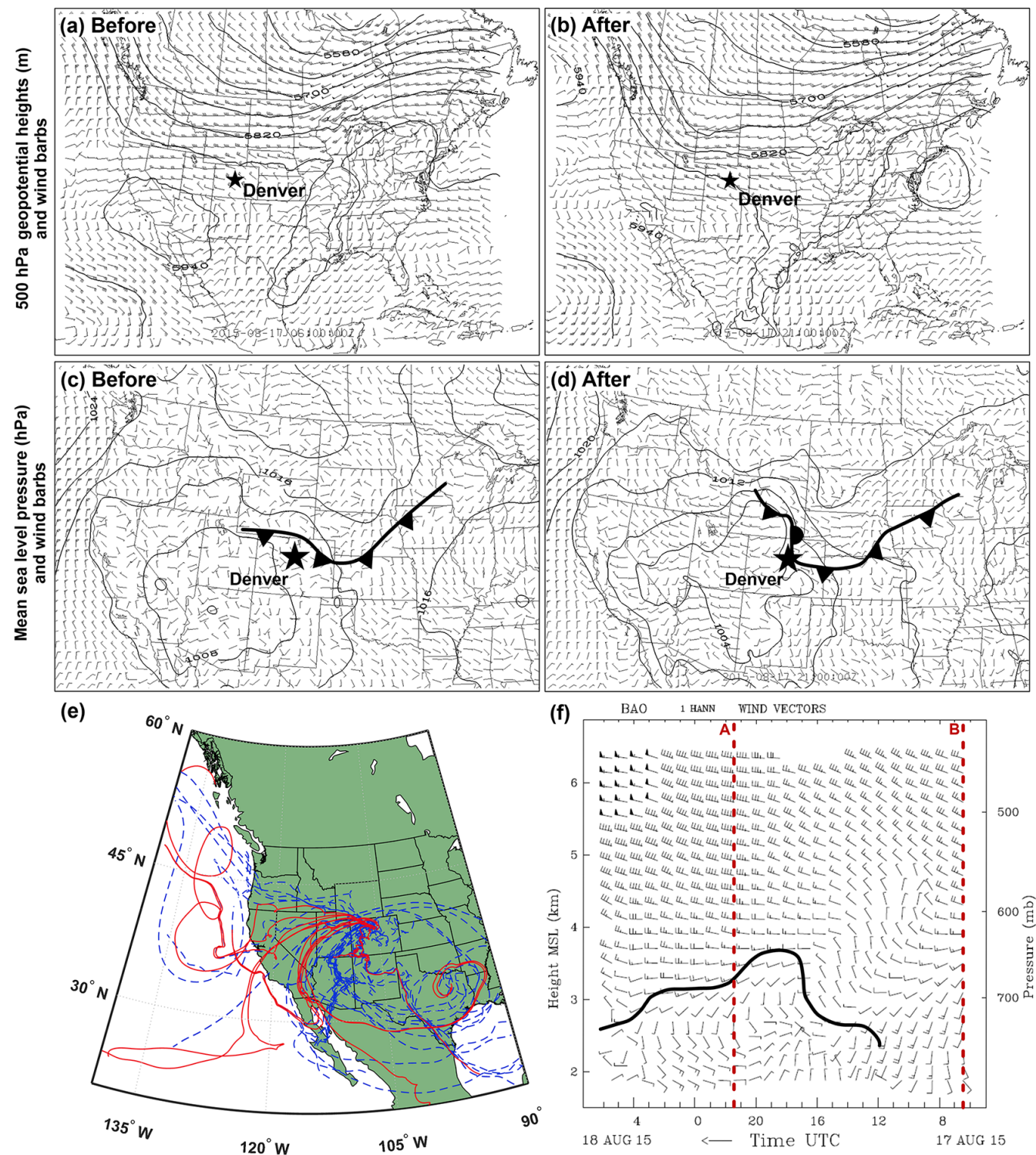

Figure 7. Meteorological analysis for event 1 (17 August 2015). Top row shows $13 \mathrm{~km}$ resolution RAP gridded dataset of $500 \mathrm{hPa}$ geopotential heights (black contours) with $500 \mathrm{hPa}$ wind velocities (flags: $25 \mathrm{~m} \mathrm{~s}^{-1}$; barbs: $5 \mathrm{~m} \mathrm{~s}^{-1}$; half barbs: $2.5 \mathrm{~m} \mathrm{~s}^{-1}$ ) from before (a) and after (b) the passage of a cold front at 06:00 and 21:00 UTC, respectively. Middle row shows mean sea-level pressure (black contours) with near-surface wind velocities (flags and barbs as above) from before (c) and after (d) the cold-frontal passage. Standard frontal notation is used. (e) Ten-day air mass backward trajectories initiated every $6 \mathrm{~h}$ at 500, 1000, and $2000 \mathrm{~m}$ a.m.s.l. during the time period surrounding event 1 (15-18 August). Trajectories in red correspond to the haziest day (17 August), and the blue dashed trajectories show the remaining. (f) Time-height section of hourly-averaged wind profiles from the $449 \mathrm{MHz}$ wind profiler at BAO between 06:00 UTC on 17 August and 06:00 UTC on 18 August (flags and barbs are as above). The bold black line denotes the approximate frontal shear boundary. The pair of red dashed lines shows the RAP analysis times before ("B") and after ("A") the cold-frontal passage at BAO. Time increases from right to left to portray the advection of upper-level synoptic features from west to east.

depicted in Fig. 1. Specifically, the blocking effect of the Rocky Mountains accelerates cold air southward along the eastern side of the high terrain (e.g., Colle and Mass, 1995; Neiman et al., 2001). Additionally, the postfrontal northerlycomponent airstream flowing across the west-east-oriented Cheyenne Ridge in southeastern Wyoming induces an anti- cyclonic gyre to the lee (south) of this ridge, subsequently shifting the postfrontal flow from northerly to easterly and driving the front westward against Colorado's Front Range (e.g., Davis, 1997; Neiman et al., 2001).

The meteorology during the second air quality event, on 22-23 August (Fig. 8), was qualitatively similar to its pre- 

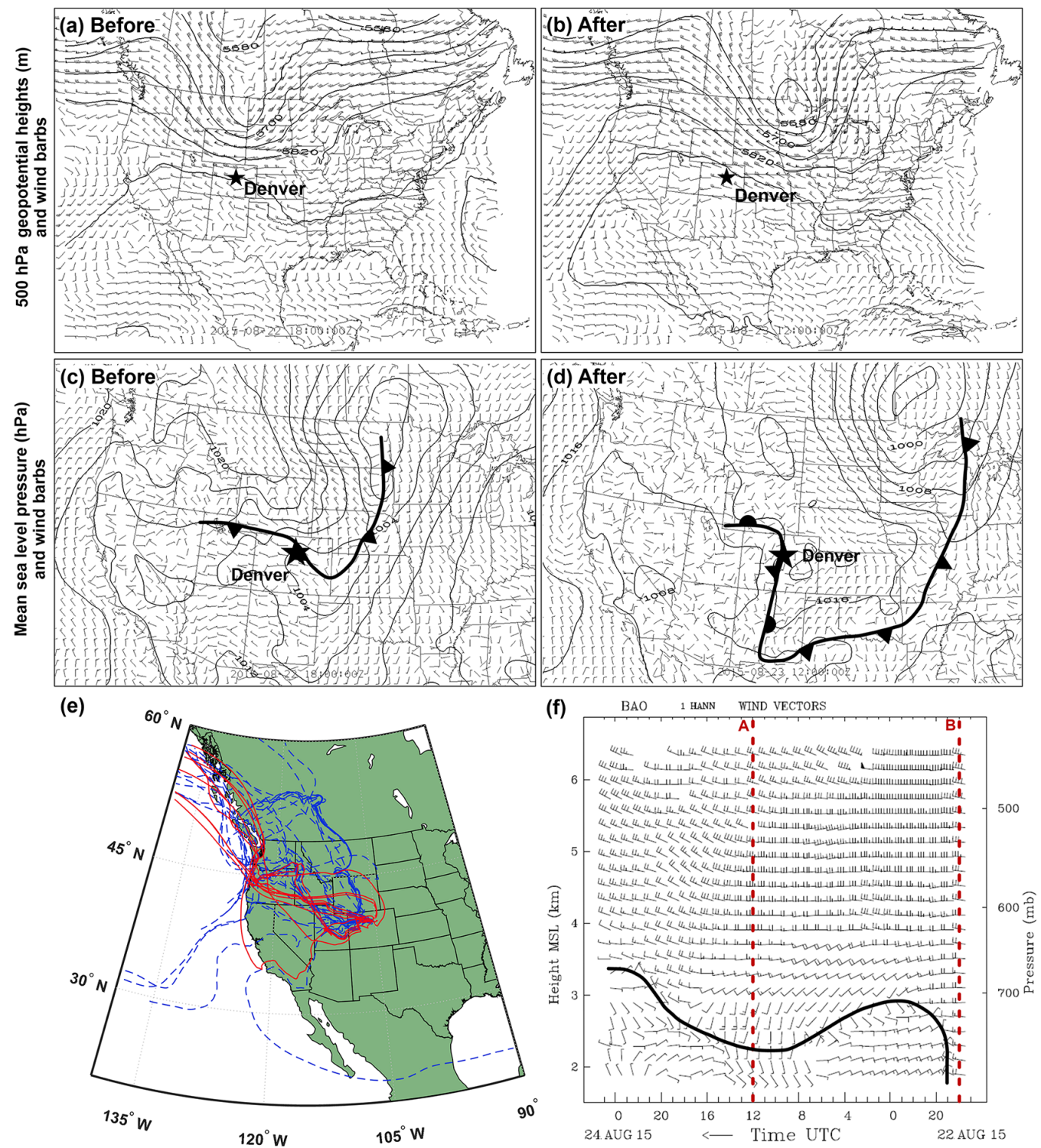

Figure 8. Same as Fig. 7 but for event 2 (23 August 2015). Before and after the cold-frontal passage correspond to 18:00 UTC on 22 August and 12:00 UTC on 23 August, respectively. Trajectories were initiated for the time period surrounding event 2 (20-23 August). Time-height section measurements were between 17:00 UTC on 22 August and 01:00 UTC on 24 August.

decessor, although the transient shortwave trough aloft was more amplified during the latter event (Fig. 8a and b). Consequently, during the second event, the terrain-trapped cold front and its trailing shallow cool air mass east of the Rockies surged much farther southward across eastern New Mexico (Fig. 8c and d). The corresponding air mass back trajectories (Fig. 8e) traveled southeastward from the Pacific Northwest fires to Colorado and passed over the fire plume region $96 \%$ of the time, leading to the worst event along the Front Range in terms of $\mathrm{PM}_{2.5}$ and total-column extinction (Fig. 3). The wind-profiler analysis at BAO (Fig. 8f) shows an abrupt low-level wind shift from westerly to easterly with the frontal passage at 19:00 UTC on 22 August, followed by a rapid deepening of the shallow cool air mass to nearly $3 \mathrm{~km}$ a.m.s.l. Thereafter, the depth of this air mass ranged between $\sim 2.2$ and $3.4 \mathrm{~km}$ a.m.s.l. Nearby rawinsonde observations at Denver from 00:00 UTC on 23 August to 00:00 UTC on 24 August (not shown) document a strong frontal inversion ranging between 3.3 and $3.8 \mathrm{~km}$ a.m.s.l., consistent with the wind-profiler analysis. Above the shallow cool air mass, the profiler shows westerly flow aloft, shifting to northwesterly with the passage of the transient shortwave trough. The largest $\mathrm{PM}_{2.5}$ values observed during this event, on $23 \mathrm{Au}$ gust, correspond to the most direct transport of air (Fig. 8e) from over the enhanced AOD regions over the Pacific Northwest fires (Fig. 5). As with the previous case, the $\mathrm{PM}_{2.5}$ 

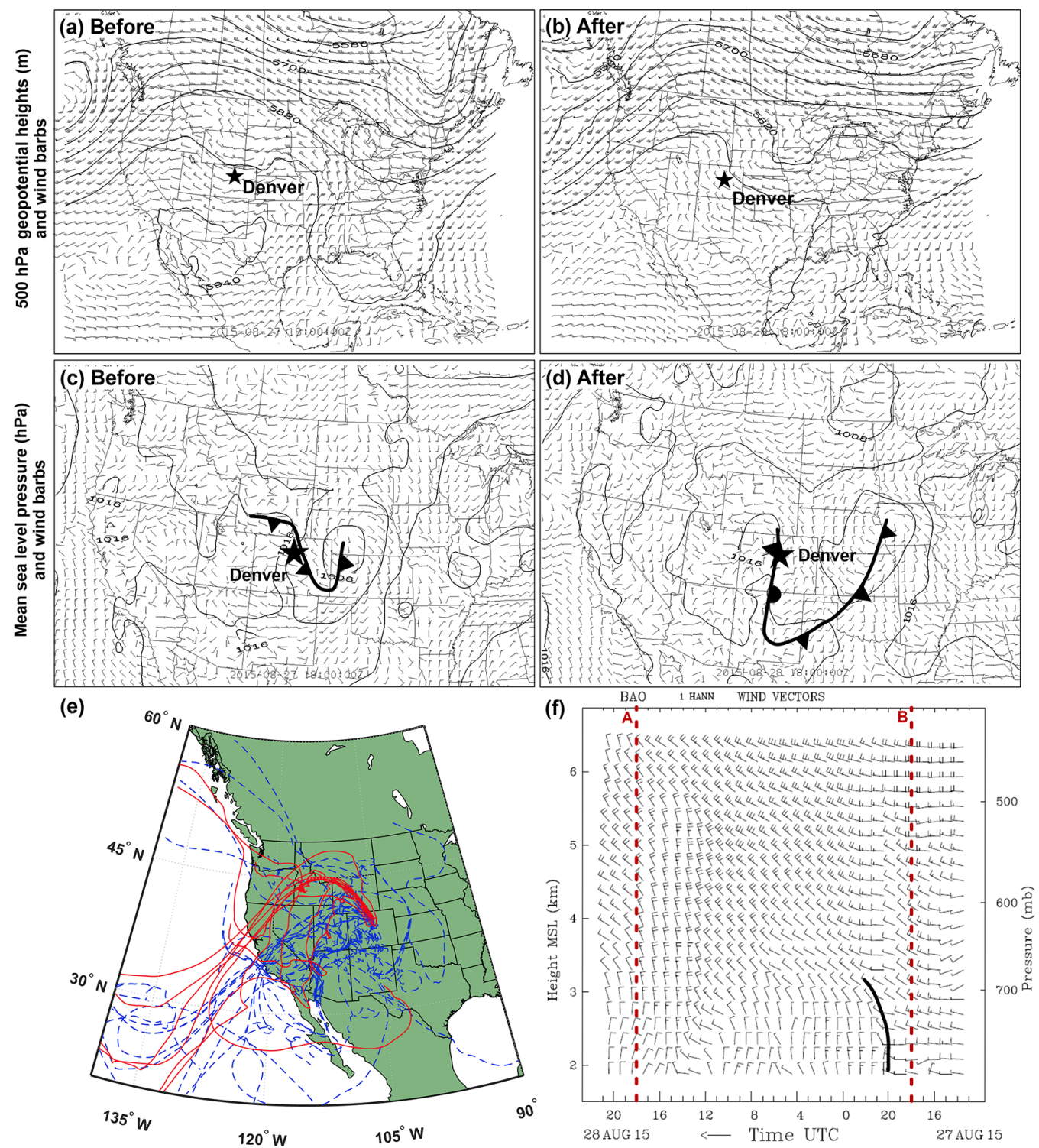

Figure 9. Same as Fig. 7 but for event 3 (29 August 2015). Before and after the cold-frontal passage correspond to 18:00 UTC on 27 August and 18:00 UTC on 28 August, respectively. Trajectories were initiated for the time period surrounding event 3 (26-29 August). Time-height section measurements were between 13:00 UTC on 27 August and 21:00 UTC on 28 August.

increased markedly with the passage of the shallow front (Fig. 3). Significantly, air quality was considerably poorer with the second event, perhaps due partly to a stronger coldfrontal push across Colorado's Front Range that originated near the smoke source region and partly due to northwesterly (rather than westerly) flow aloft that could transport the smoke through a deeper layer toward Colorado. Further, more fires were detected during the second event (678, on average) compared to the first event (231 fires, on average); thus the larger number of fires could result in more smoke production and thus a denser smoke plume transported to the Front Range.
The synoptic-scale conditions on 27-28 August (Fig. 9) associated with the third air quality case differ considerably from those of the two earlier events. Most significantly, a broad ridge aloft covered the intermountain West for the duration of this final event, while an embedded weak shortwave trough migrated eastward through the ridge from WyomingColorado to the Great Plains (Fig. 9a and b). A surface reflection of the upper-level shortwave trough was manifested as a weak low-pressure center over western Nebraska and Kansas at 18:00 UTC on 27 August (Fig. 9c). This low migrated eastward during the subsequent $24 \mathrm{~h}$ (Fig. 9d) in tandem with the upper-level shortwave. Because this surface low resided beneath a mean ridge aloft, the temperature contrast across 

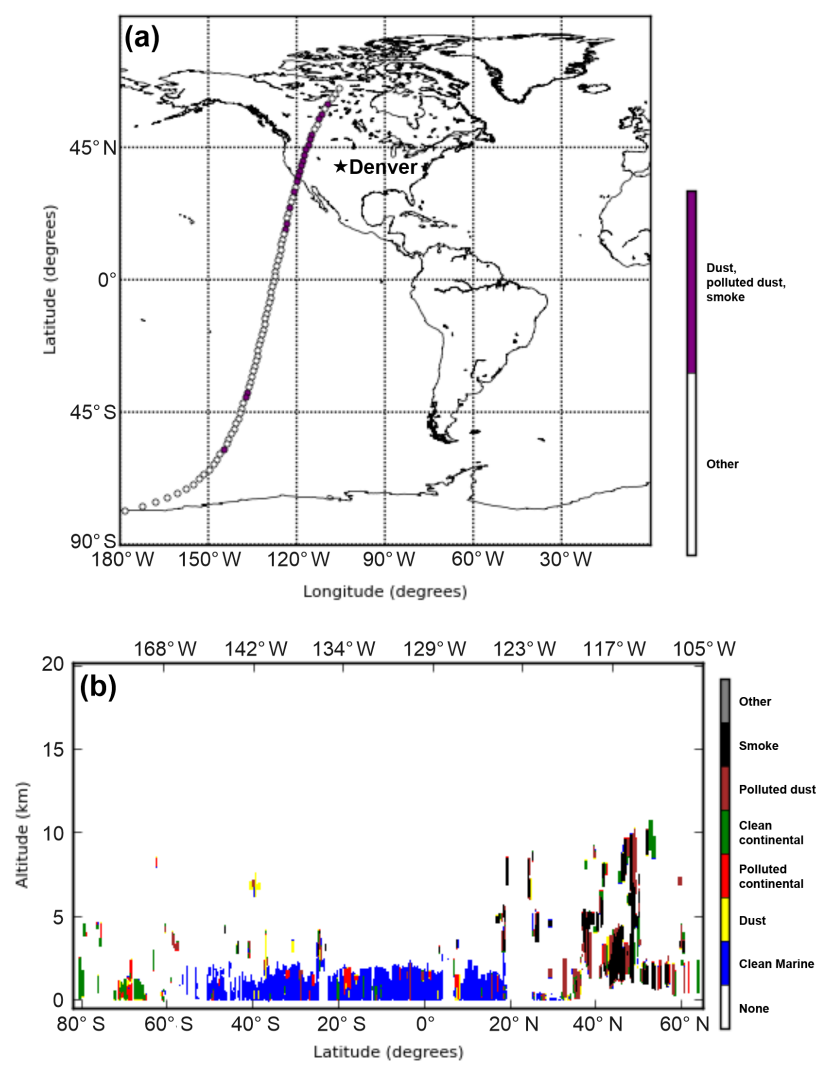

Figure 10. CALIPSO swath data from the night prior to event 1 . Swath data contained in the CAL_LID_L2_VFM_ValState1-V3-30 file are from 16 August 2015 at 09:57:00 UTC. (a) Map showing CALIPSO coverage, with the purple markers representing locations in the column measurement where dust, smoke, or polluted dust were observed. (b) Vertical profile (in km a.m.s.l.) for all aerosol subtypes of the swath corresponding to (a).

this trailing cold front was weaker than its earlier counterparts (not shown). Nevertheless, the southward migration of the front east of the Rockies suggests that terrain blocking may have influenced its evolution. The air mass back trajectories show parcels originating from the region of the fires and enhanced AOD $85 \%$ of the time, similar to the trajectories from the earlier two events (Fig. 9e). Companion observations from the $\mathrm{BAO}$ wind profiler (Fig. 9f) capture the shallow frontal passage at 20:00 UTC on 27 August, when westerly flow shifted abruptly to northerly. Above $3 \mathrm{~km}$ a.m.s.l., the wind field exhibited a more gradual transition from westerly to northwesterly as the weak shortwave trough moves across the wind profiler. The Denver rawinsondes at 00:00 and 12:00 UTC on 28 August observed a frontal inversion at $\sim 2.1 \mathrm{~km}$ a.m.s.l. (not shown). It was less prominent than the frontal inversions during the earlier events, largely because the temperature contrast across this front was weaker than its predecessors. The subsequent rawinsonde profile at 00:00 UTC on 29 August (not shown) captured a deep, dry-

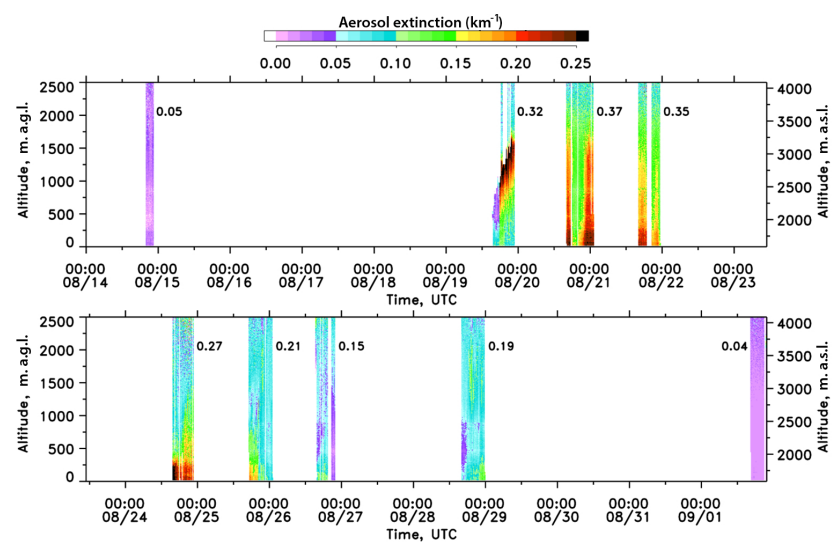

Figure 11. Aerosol extinction profiles at $294 \mathrm{~nm}$ observed with the TOPAZ lidar on 9 days during the smoke pollution episodes. The numbers next to each day's observations represent the daily mean AOD from the surface up to $2.5 \mathrm{~km}$ a.g.l. computed from the lidar measurements.

convective boundary layer extending up to $4 \mathrm{~km}$ a.m.s.l., despite persistent low-level northerly flow. Sensible heating eroded the remnant low-level cool air east of the Rockies. $\mathrm{PM}_{2.5}$ increased following the initial shallow cold-frontal passage at 20:00 UTC on 27 August and continued to increase for the remainder of the wind-profiler time-height section, as deep northerly-component flow behind the weak shortwave trough transported smoke particulates across Colorado.

\subsection{Mineral dust and smoke arrive along the Front Range}

The types of aerosols present in the enhanced AOD plumes that were transported towards the Front Range via the aforementioned synoptic conditions were evaluated using additional satellite-based measurements and support the interpretation of transport of aerosols from the wildfires in the Pacific Northwest to Colorado. Figure 10 shows aerosol subtype data from the CALIPSO satellite in planar (a panel) and vertical-profile (b panel) views during event 1 . CALIPSO data were strikingly similar for events 2 and 3 and are provided in the Supplement. Only the worst day or the day prior to the worst day of each haze event is shown, although aerosol subtype data were examined anytime CALIPSO passed over the Pacific Northwest or Colorado from $15 \mathrm{Au}-$ gust to 2 September. CALIPSO demonstrates the presence of smoke, dust, or polluted dust (dust mixed with smoke in each profile) during times that intersect the enhanced AOD plume propagating from the Pacific Northwest or when over Colorado. Dust and smoke plumes from the fires extended up to $10 \mathrm{~km}$ a.m.s.l. over the western US. The mineral dust and smoke detected by CALIPSO in transit to the Front Range were also detected with the TOPAZ lidar and the in situ aerosol particle mass and speciation monitor at 
the DSRC. Figure 11 shows aerosol extinction profiles from the surface to $2.5 \mathrm{~km}$ a.g.1. measured with the TOPAZ lidar on 9 days during the smoke episodes. The time resolution of the extinction profiles is $5 \mathrm{~min}$, and the vertical resolution is $1 \mathrm{~m}$ at the lowest altitudes, increasing to $6 \mathrm{~m}$ above 500 ma.g.l. The observations on 14 August and 2 September, which bracket the smoke episodes, indicate very clean conditions with AOD from the surface up to $2.5 \mathrm{~km}$ a.g.1. $\left(\mathrm{AOD}_{2.5 \mathrm{~km}}\right)$ of 0.05 and 0.04 , respectively. Aerosol extinction coefficients and $\mathrm{AOD}_{2.5 \mathrm{~km}}$ were significantly larger during the smoke episodes with an approximately sevenfold increase in $\mathrm{AOD}_{2.5 \mathrm{~km}}$ on 20 and 21 August. This time period also corresponds to increasing extinction at DESCI (Fig. 3). Aerosol extinction was enhanced over the entire $2.5 \mathrm{~km}$ column, but the largest aerosol extinction values were observed in the boundary layer in the lowest few hundred meters up to $1.5 \mathrm{~km}$ a.g.l. Also, the lidar measurements reveal that on most days aerosol extinction varied significantly over the course of the day (e.g., 20 August). The largest aerosol extinction values, around $1-1.5 \mathrm{~km}$ a.g.l., observed on 19 August were primarily due to swelling of aerosol particles in the moist relative-humidity environment beneath cumulus clouds at the top of the boundary layer. However, aerosol extinction in the lower part of the boundary was still significantly larger than on 14 August, which is consistent with the larger aerosol particle concentrations in the smoke plumes. The lidar measurements are consistent with the atmospheric extinction measurements from DESCI and the in situ $\mathrm{PM}_{2.5}$ and MODIS AOD observations. When comparing lidar $\mathrm{AOD}_{2.5} \mathrm{~km}$ with MODIS AOD, one has to be cognizant of the fact that the TOPAZ observations only cover a portion of the atmospheric column and that the two AOD measurements were made at different wavelengths. A comparison between the near-surface TOPAZ and DESCI extinction observations also needs to take into account that the measurements were made at different wavelengths.

Figure 12 shows the time series of $\mathrm{PM}_{2.5}$, soil mass concentrations, and elemental mass concentrations (data from the PX-375 were not available prior to this time period due to instrumental complications). Soil concentrations were calculated by following the Interagency Monitoring of Protected Visual Environments (IMPROVE) convention using concentrations of specific metals: soil $=2.2[\mathrm{Al}]+2.49[\mathrm{Si}]+1.63[\mathrm{Ca}]+2.42[\mathrm{Fe}]+1.94[\mathrm{Ti}]$

(Malm et al., 1994; Hand et al., 2011). Both PM$_{2.5}$ and soil mass concentrations increased during the worst haze event days (i.e., 26 and 29 August), when the Pacific Northwest fires were influencing air along the Front Range and when CALIPSO showed the presence of smoke and dust over the western US. The diurnal pattern is likely caused by the upslope/downslope flow patterns due to proximity from the base of the foothills, which is particularly pronounced in the summer (Toth and Johnson, 1985). Further, select metals also increased in concentration during haze events, particularly those typically sourced from mineral dust (i.e.,

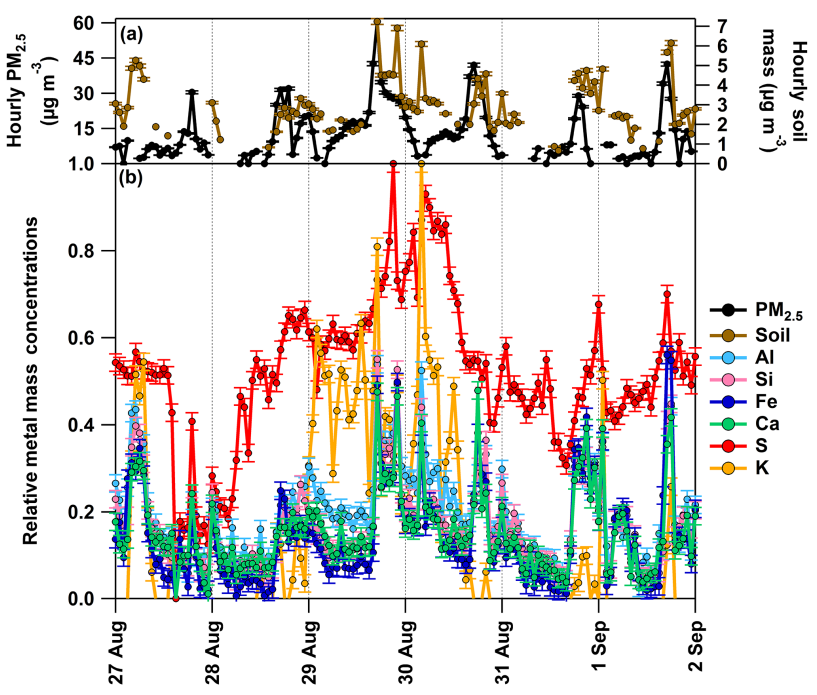

Figure 12. (a) Time series of hourly $\mathrm{PM}_{2.5}$ and soil mass concentrations as measured by PX-375 between 27 August and 2 September 2015 and (b) hourly mass concentrations of select individual metals relative to their maximum concentration observed during the study time period, including an error of $\pm 2 \%$. Only data higher than the LDLs are shown. PX-375 data overlapped with event 3.

in the IMPROVE soil convention equation) and $\mathrm{S}$ and $\mathrm{K}$, which are metal tracers that have been observed in smoke or biomass burning aerosols originating from fires (Artaxo et al., 1994; Gaudichet et al., 1995; Yamasoe et al., 2000; Pachon et al., 2013). It is important to note that $\mathrm{K}$ may also originate from soil. We calculated the soil $\mathrm{K}$ and non-soil $\mathrm{K}$ based on the methods of Kreidenweis et al. (2001), which are shown in the Supplement. Concentrations of both soil $\mathrm{K}$ and non-soil $\mathrm{K}$ were highest during the influence from the fires. Additionally, IMPROVE measurements at the Rocky Mountain National Park location showed higher concentrations of soil, S, and K during event days in August, corroborating our measurements (see Supplement).

Figure 13 shows the average concentrations of mineral dust or biomass burning metal tracers from the PX-375 from 26 August to 2 September, during conditions influenced by the Pacific Northwest fires (days with enhanced $\mathrm{PM}_{2.5}$, 2930 August) and days with cleaner, normal Front Range conditions (days with low $\mathrm{PM}_{2.5}$, remaining days during this time period). $\mathrm{PM}_{2.5}$ and soil mass, biomass burning metal ( $\mathrm{S}$ and $\mathrm{K}$ ), and mineral dust marker ( $\mathrm{Al}, \mathrm{Si}, \mathrm{Fe}$, and $\mathrm{Ca}$ ) concentrations were all larger, on average, during influences from the Pacific Northwest fires, corroborating the CALIPSO observations. It is important to note the possibility that some small concentration of $\mathrm{Ca}, \mathrm{Al}$, and $\mathrm{Fe}$ could also originate from biomass burning, although the apportionment of this source remains in question, and their contribution from biomass burning aerosol is likely minor in comparison to their concentrations in mineral dust (Chang-Graham et al., 


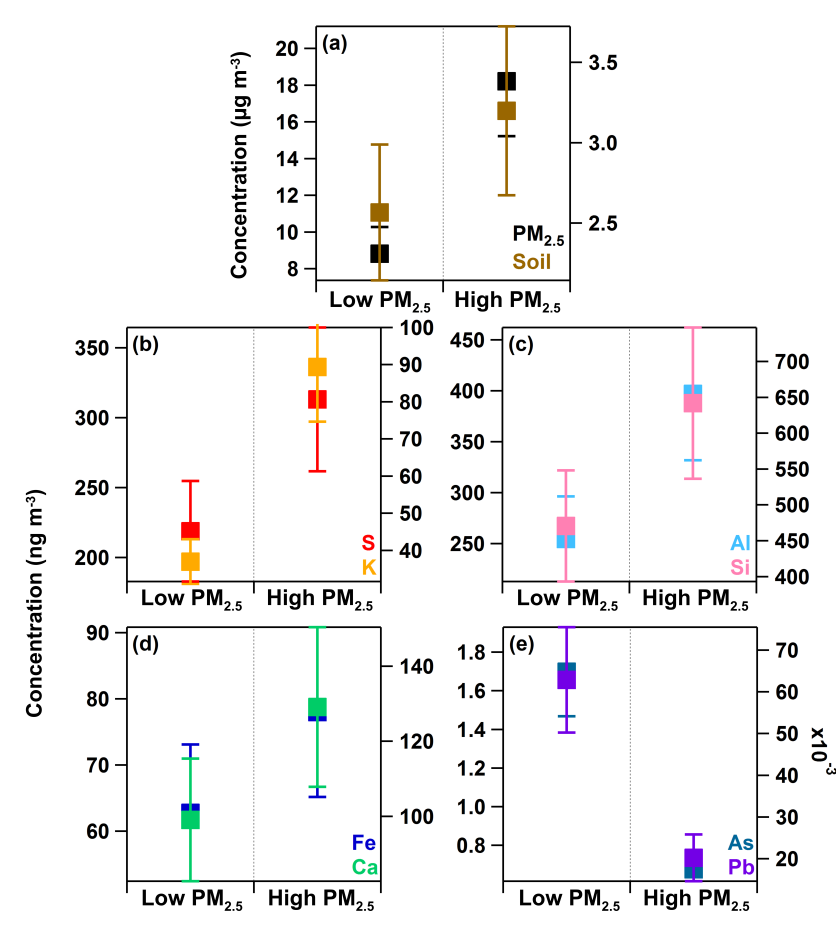

Figure 13. Averages of (a) $\mathrm{PM}_{2.5}$ and soil concentrations and (be) select metal mass concentrations during non-event days (i.e., cleaner conditions) compared to averages from haze event days (i.e., influence from fires haze) for 26 August-2 September 2015. "Low" and "high" correspond to the $\mathrm{PM}_{2.5}$ concentration values. Error bars represent the $90 \%$ confidence intervals. Concentration averages were statistically significant based on $t$ tests of two samples of unequal variances.

2011). Also included are metals that are typical of industrial tracers As and Pb (Fig. 13e) (Paciga and Jervis, 1976; Hutton and Symon, 1986; Thomaidis et al., 2003), which were actually lower in concentration during influences from wildfires and enhanced during normal, regionally sourced influences. The average $\mathrm{PM}_{2.5}$ mass concentration from the CDPHE data was almost 3 times larger on 29-30 August as compared to the remaining days in the 26 August-2 September time period (15.9 vs. $5.7 \mu \mathrm{g} \mathrm{m}^{-3}$, respectively). This result demonstrates how influences from typical regional industrial sources is disrupted by the synoptic conditions that introduced the long-range-transported biomass burning plumes. Although $\mathrm{Zn}$ and $\mathrm{Cu}$ have been shown to originate from wildfires (Yamasoe et al., 2000), the averages were similar - within $1 \mathrm{ng} \mathrm{m}^{-3}$ - and thus a distinct comparison could not be made within certainty. Further, these metals can also be derived from vehicular emissions; thus their concentrations may additionally be influenced by local traffic (Sternbeck et al., 2002). These results demonstrate the transport of mineral dust and biomass burning aerosol species to the Front Range, which were indeed larger in concentration during poor-airquality/haze events. Interestingly, mineral dust mixed within a smoke plume from fires has predominantly been observed originating from more arid regions along the global dust belt and using modeling or remote-sensing data only (e.g., Radojevic, 2003; Tesche et al., 2009; Yang et al., 2013; Nisantzi et al., 2014). To our knowledge, this co-lofting of dust and smoke has not been shown to occur in the US, particularly in a region as densely covered in vegetation as the Pacific Northwest.

\section{Conclusions}

We have demonstrated the transport of mineral dust and smoke/biomass burning aerosols from wildfires in the $\mathrm{Pa}$ cific Northwest to the Colorado Front Range using a combination of in situ, remote-sensing, and air parcel modeling techniques (M. Severijnen, personal communication, 2015). These aerosols were transported under synoptic conditions that contributed to three different haze events, inducing poor air quality in the Denver metro area. Three separate poor-airquality events with enhanced $\mathrm{PM}_{2.5}$ were likely dependent on the number of fires and observed to occur with cold-frontal passages along Colorado's Front Range, enabling the enhanced AOD plumes originating from the Pacific Northwest wildfires to propagate southeastward to Colorado's Front Range. Air masses were shown to originate from over the region dense with wildfires and followed through satellitedetected aerosol plumes, which were rich in a mixture of mineral dust and smoke. Tracers for these aerosol types were also detected in situ along the Front Range and were shown to be enhanced during periods of influence from the fires.

Overall, these unique observations were demonstrated using a complete suite of in situ and remote-sensing aerosol measurements in the context of in situ meteorological observations and air mass trajectory modeling. In tandem, we utilized a real-time X-ray fluorescence spectroscopy technique using the novel and field-portable PX-375 from HORIBA, Ltd., demonstrating the utility of the instrument. Although the haze events were short lived, they demonstrate how quickly (i.e., on the order of 2 to 3 days from the fire region to the Front Range) aerosols can be transported long distances and affect air quality in regions thousands of kilometers away. Interestingly, mineral dust was observed to be co-lofted and transported within the smoke plumes, an observation not previously reported for vegetated regions such as the Pacific Northwest.

Mineral dust and smoke aerosols have disparate implications for health and climate, particularly at the levels observed along the Front Range. These unique observations should be taken into account when developing health standards, seeing as not only regional urban and industrial emissions contribute to poor air quality conditions. Additionally, dust and smoke are efficient cloud-forming nuclei - which impacts cloud lifetime, radiative effects, and precipitation formation mechanisms - particularly when orographically 
lifted along barriers such as the Front Range into the upper atmosphere, where cloud formation is prominent. Thus, transport of these aerosols from wildfires has broad implications for altering aerosol composition in regions far from the source.

\section{Data availability}

Raw CDPHE data are available from http://www.colorado. gov/airquality/report.aspx. Validated CDPHE data are available at request by contacting CDPHE directly. MODIS thermal anomaly data are available at https://worldview. earthdata.nasa.gov/. MODIS AOD data are available at https://search.earthdata.nasa.gov/. CALIPSO data are available at http://reverb.echo.nasa.gov/reverb/?keywords= CAL_LID_L2_VFM-ValStage1-V3-30\&selected= C6770313-LARC_ASDC\#utf8=\%E2\%9C\%93\&spatial_ map $=$ satellite $\&$ spatial_type $=$ rectangle $\&$ spatial $=$ 19C0-97C069C0115\&keywords=CAL_LID_L2_ VFM-ValStage1-V3-30\&temporal_start=2015-08-15000\% 3A00\%3A00\&temporal_end=2015-09-06023\% 3A59\%3A59\&selected=C7399830-LARC_ASDC. GDAS data used for HYSPLIT are available at ftp://arlftp.arlhq.noaa.gov/pub/archives/gdas1. TOPAZ data are available at request by contacting Christoph J. Senff (christoph.senff@noaa.gov). PX-375 data are available at request by contacting the corresponding author, Jessie M. Creamean (jessie.creamean@ noaa.gov).

\section{The Supplement related to this article is available online at doi:10.5194/acp-16-12329-2016-supplement.}

Author contributions. Jessie M. Creamean analyzed XRF data, compiled CDPHE and MODIS data, ran HYSPLIT simulations, and wrote the manuscript. Paul J. Neiman conducted meteorological analysis and interpretation. Timothy Coleman compiled and analysed CALIPSO data. Christoph J. Senff, Guillaume Kirgis, and Raul J. Alvarez analysed and supplied TOPAZ data. Atsushi Yamamoto provided PX-375 for usage. All co-authors contributed to the writing of or provided comments for the manuscript.

Acknowledgements. The authors would like to acknowledge the many agencies and organization from which data were acquired, including the CDPHE for air quality data, NASA for MODIS and CALIPSO observations, NOAA for HYSPLIT and HMT meteorological data, and the HDF group for providing example code to process CALIPSO data.

Edited by: H. Wang

Reviewed by: two anonymous referees

\section{References}

Ackerman, S. A., Strabala, K. I., Menzel, W. P., Frey, R. A., Moeller, C. C., and Gumley, L. E.: Discriminating clear sky from clouds with MODIS, J. Geophys. Res.-Atmos., 103, 3214132157, 1998.

Alvarez, R. J., Senff, C. J., Langford, A. O., Weickmann, A. M., Law, D. C., Machol, J. L., Merritt, D. A., Marchbanks, R. D., Sandberg, S. P., Brewer, W. A., Hardesty, R. M., and Banta, R. M.: Development and Application of a Compact, Tunable, SolidState Airborne Ozone Lidar System for Boundary Layer Profiling, J. Atmos. Ocean. Tech., 28, 1258-1272, 2011.

Alvarez, R. J., Senff, C. J., Weickmann, A. M., Sandberg, S. P., Langford, A. O., Marchbanks, R. D., Brewer, W. A., and Hardesty, R. M.: Reconfiguration of the NOAA TOPAZ lidar for ground-based measurement of ozone and aerosol backscatter, Proceedings of the 26th International Laser Radar Conference, Porto Heli, Greece, 2012.

Ansmann, A., Baars, H., Tesche, M., Muller, D., Althausen, D., Engelmann, R., Pauliquevis, T., and Artaxo, P.: Dust and smoke transport from Africa to South America: Lidar profiling over Cape Verde and the Amazon rainforest, Geophys. Res. Lett., 36, L11802, doi:10.1029/2009GL037923, 2009.

Artaxo, P., Gerab, F., Yamasoe, M. A., and Martins, J. V.: Fine Mode Aerosol Composition at 3 Long-Term Atmospheric Monitoring Sites in the Amazon Basin, J. Geophys. Res.-Atmos., 99, $22857-$ 22868, 1994.

Baars, H., Ansmann, A., Althausen, D., Engelmann, R., Artaxo, P., Pauliquevis, T., and Souza, R.: Further evidence for significant smoke transport from Africa to Amazonia, Geophys. Res. Lett., 38, L20802, doi:10.1029/2011GL049200, 2011.

Benjamin, S. G., Weygandt, S. S., Brown, J. M., Hu, M., Alexander, C. R., Smirnova, T. G., Olson, J. B., James, E. P., Dowell, D. C., Grell, G. A., Lin, H., Peckham, S. E., Smith, T. L., Moninger, W. R., Kenyon, J. S., and Manikin, G. S.: A North American Hourly Assimilation and Model Forecast Cycle: The Rapid Refresh, Mon. Weather Rev., 144, 1669-1694, 2016.

Bowman, D. J. S. and Johnston, F.: Wildfire Smoke, Fire Management, and Human Health, EcoHealth, 2, 76-80, 2005.

Bravo, A. H., Sosa, E. R., Sanchez, A. P., Jaimes, P. M., and Saavedra, R. M. I.: Impact of wildfires on the air quality of Mexico City, 1992-1999, Environ. Pollut., 117, 243-253, 2002.

Brown, S. S., Thornton, J. A., Keene, W. C., Pszenny, A. A. P., Sive, B. C., Dube, W. P., Wagner, N. L., Young, C. J., Riedel, T. P., Roberts, J. M., VandenBoer, T. C., Bahreini, R., Ozturk, F., Middlebrook, A. M., Kim, S., Hubler, G., and Wolfe, D. E.: Nitrogen, Aerosol Composition, and Halogens on a Tall Tower (NACHTT): Overview of a wintertime air chemistry field study in the front range urban corridor of Colorado, J. Geophys. Res.Atmos., 118, 8067-8085, 2013.

Chalbot, M. C., Nikolich, G., Etyemezian, V., Dubois, D. W., King, J., Shafer, D., da Costa, G. G., Hinton, J. F., and Kavouras, I. G.: Soil humic-like organic compounds in prescribed fire emissions using nuclear magnetic resonance spectroscopy, Environ. Pollut., 181, 167-171, 2013.

Chang-Graham, A. L., Profeta, L. T. M., Johnson, T. J., Yokelson, R. J., Laskin, A., and Laskin, J.: Case Study of Water-Soluble Metal Containing Organic Constituents of Biomass Burning Aerosol, Environ. Sci. Technol., 45, 1257-1263, 2011. 
Clements, C. B., Zhong, S. Y., Bian, X. D., Heilman, W. E., and Byun, D. W.: First observations of turbulence generated by grass fires, J. Geophys. Res.-Atmos., 113, D22102, doi:10.1029/2008JD010014, 2008.

Colarco, P. R., Schoeberl, M. R., Doddridge, B. G., Marufu, L. T., Torres, O., and Welton, E. J.: Transport of smoke from Canadian forest fires to the surface near Washington, D. C.: Injection height, entrainment, and optical properties, J. Geophys. Res.Atmos., 109, D06203, doi:10.1029/2003JD004248, , 2004.

Colle, B. A. and Mass, C. F.: The Structure and Evolution of Cold Surges East of the Rocky-Mountains, Mon. Weather Rev., 123, 2577-2610, 1995.

Cruz, C. N. and Pandis, S. N.: A study of the ability of pure secondary organic aerosol to act as cloud condensation nuclei, Atmos. Environ., 31, 2205-2214, 1997.

Davis, C. A.: Mesoscale anticyclonic circulations in the Lee of the central Rocky Mountains, Mon. Weather Rev., 125, 2838-2855, 1997.

DeMott, P. J., Chen, Y., Kreidenweis, S. M., Rogers, D. C., and Sherman, D. E.: Ice formation by black carbon particles, Geophys. Res. Lett., 26, 2429-2432, 1999.

DeMott, P. J., Sassen, K., Poellot, M. R., Baumgardner, D., Rogers, D. C., Brooks, S. D., Prenni, A. J., and Kreidenweis, S. M.: African dust aerosols as atmospheric ice nuclei, Geophys. Res. Lett., 30, 1732, doi:10.1029/2003GL017410, 2003.

Draxler, R. R. and Rolph, G. D.: HYSPLIT (HYbrid Single-Particle Lagrangian Integrated Trajectory) Model access via NOAA ARL READY Website, http://ready.arl.noaa.gov/HYSPLIT.php (last access: 8 July 2016), 2011.

Eagan, R. C., Hobbs, P. V., and Radke, L. F.: Measurements of Cloud Condensation Nuclei and Cloud Droplet Size Distributions in Vicinity of Forest Fires, J. Appl. Meteorol., 13, 553-557, 1974.

Gadi, R., Kulshrestha, U. C., Sarkar, A. K., Garg, S. C., and Parashar, D. C.: Emissions of $\mathrm{SO}_{2}$ and $\mathrm{NO}_{x}$ from biofuels in India, Tellus B, 55, 787-795, 2003.

Gaudichet, A., Echalar, F., Chatenet, B., Quisefit, J. P., Malingre, G., Cachier, H., Buatmenard, P., Artaxo, P., and Maenhaut, W.: Trace-Elements in Tropical African Savanna Biomass Burning Aerosols, J. Atmos. Chem., 22, 19-39, 1995.

Ge, C., Wang, J., and Reid, J. S.: Mesoscale modeling of smoke transport over the Southeast Asian Maritime Continent: coupling of smoke direct radiative effect below and above the low-level clouds, Atmos. Chem. Phys., 14, 159-174, doi:10.5194/acp-14159-2014, 2014.

Giglio, L.: MODIS Collection 5 Active Fire Product User's Guide Version 2.4, Science Systems and Applications, Inc., 2010.

Giglio, L., Descloitres, J., Justice, C. O., and Kaufman, Y. J.: An enhanced contextual fire detection algorithm for MODIS, Remote Sens. Environ., 87, 273-282, 2003.

Haagenson, P. L.: Meteorological and Climatological Factors Affecting Denver Air-Quality, Atmos. Environ., 13, 79-85, 1979.

Hand, J. L., Copland, S. A., Dillner, A. M., Indresand, H., Malm, W. C., McDade, C. E., Moore, C. T., Pitchford, M. L., Schichtel, B. A., and Watson, J. G.: Spatial and Seasonal Patterns and Temporal Variability of Haze and its Constituents in the United States Report V Cooperative Institute for Research in the Atmosphere, 2011.
Hutton, M. and Symon, C.: The Quantities of Cadmium, Lead, Mercury and Arsenic Entering the Uk Environment from Human Activities, Sci. Total Environ., 57, 129-150, 1986.

Jacob, D. J. and Winner, D. A.: Effect of climate change on air quality, Atmos. Environ., 43, 51-63, 2009.

Jaffe, D. A. and Wigder, N. L.: Ozone production from wildfires: A critical review, Atmos. Environ., 51, 1-10, 2012.

Jayachandran, S.: Air quality and early-life mortality: Evidence from Indonesia's wildfires, J. Human Resources, 44, 916-954, 2008.

Kalnay, E., Kanamitsu, M., Kistler, R., Collins, W., Deaven, D., Gandin, L., Iredell, M., Saha, S., White, G., Woollen, J., Zhu, Y., Chelliah, M., Ebisuzaki, W., Higgins, W., Janowiak, J., Mo, K. C., Ropelewski, C., Wang, J., Leetmaa, A., Reynolds, R., Jenne, R., and Joseph, D.: The NCEP/NCAR 40-year reanalysis project, B. Am. Meteorol. Soc., 77, 437-471, 1996.

Kaufman, Y. J., Tanre, D., Remer, L. A., Vermote, E. F., Chu, A., and Holben, B. N.: Operational remote sensing of tropospheric aerosol over land from EOS moderate resolution imaging spectroradiometer, J. Geophys. Res.-Atmos., 102, 17051-17067, 1997.

Kreidenweis, S. M., Remer, L. A., Bruintjes, R., and Dubovik, O.: Smoke aerosol from biomass burning in Mexico: Hygroscopic smoke optical model, J. Geophys. Res.-Atmos., 106, 4831-4844, 2001.

Liu, Y. Q., Stanturf, J., and Goodrick, S.: Trends in global wildfire potential in a changing climate, Forest Ecol. Manag., 259, 685697, 2010.

Malm, W. C., Sisler, J. F., Huffman, D., Eldred, R. A., and Cahill, T. A.: Spatial and Seasonal Trends in Particle Concentration and Optical Extinction in the United-States, J. Geophys. Res.Atmos., 99, 1347-1370, 1994.

McCluskey, C. S., DeMott, P. J., Prenni, A. J., Levin, E. J. T., McMeeking, G. R., Sullivan, A. P., Hill, T. C. J., Nakao, S., Carrico, C. M., and Kreidenweis, S. M.: Characteristics of atmospheric ice nucleating particles associated with biomass burning in the US: Prescribed burns and wildfires, J. Geophys. Res.Atmos., 119, 10458-10470, doi:10.1002/2014JD021980, 2014.

Moore, D., Copes, R., Fisk, R., Joy, R., Chan, K., and Brauer, M.: Population Health Effects of Air Quality Changes Due to Forest Fires in British Columbia in 2003: Estimates from Physicianvisit Billing Data, C. J. Public Health, 97, 105-108, 2006.

Mott, J. A., Meyer, P., Mannino, D., Redd, S. C., Smith, E. M., Gotway-Crawford, C., and Chase, E.: Wildland forest fire smoke: health effects and intervention evaluation,Hoopa, California, 1999, Western J. of Med., 176, 157-162, 2002.

Neff, J. C., Ballantyne, A. P., Farmer, G. L., Mahowald, N. M., Conroy, J. L., Landry, C. C., Overpeck, J. T., Painter, T. H., Lawrence, C. R., and Reynolds, R. L.: Increasing eolian dust deposition in the western United States linked to human activity, Nat. Geosci., 1, 189-195, 2008

Neiman, P. J., Ralph, F. M., Weber, R. L., Uttal, T., Nance, L. B., and Levinson, D. H.: Observations of nonclassical frontal propagation and frontally forced gravity waves adjacent to steep topography, Mon. Weather Rev., 129, 2633-2659, 2001.

Nisantzi, A., Mamouri, R. E., Ansmann, A., and Hadjimitsis, D.: Injection of mineral dust into the free troposphere during fire events observed with polarization lidar at Limassol, Cyprus, 
Atmos. Chem. Phys., 14, 12155-12165, doi:10.5194/acp-1412155-2014, 2014

Nriagu, J. O.: A Global Assessment of Natural Sources of Atmospheric Trace-Metals, Nature, 338, 47-49, 1989.

Omar, A. H., Winker, D. M., Kittaka, C., Vaughan, M. A., Liu, Z. Y., Hu, Y. X., Trepte, C. R., Rogers, R. R., Ferrare, R. A., Lee, K. P., Kuehn, R. E., and Hostetler, C. A.: The CALIPSO Automated Aerosol Classification and Lidar Ratio Selection Algorithm, J. Atmos. Ocean. Tech., 26, 1994-2014, 2009.

Pachon, J. E., Weber, R. J., Zhang, X. L., Mulholland, J. A., and Russell, A. G.: Revising the use of potassium (K) in the source apportionment of $\mathrm{PM}_{2.5}$, Atmos. Pollut. Res., 4, 14-21, 2013.

Paciga, J. J. and Jervis, R. E.: Multielement Size Characterization of Urban Aerosols, Environ. Sci. Technol., 10, 1124-1128, 1976.

Park, R. J., Jacob, D. J., Chin, M., and Martin, R. V.: Sources of carbonaceous aerosols over the United States and implications for natural visibility, J. Geophys. Res.-Atmos., 108, 4355, doi:10.1029/2002JD003190, 2003.

Peterson, D., Hyer, E., and Wang, J.: Quantifying the potential for high-altitude smoke injection in the North American boreal forest using the standard MODIS fire products and subpixel-based methods, J. Geophys. Res.-Atmos., 119, 3401-3419, 2014.

Phuleria, H. C., Fine, P. M., Zhu, Y. F., and Sioutas, C.: Air quality impacts of the October 2003 Southern California wildfires, J. Geophys. Res.-Atmos., 110, D07S20, doi:10.1029/2004JD004626, 2005.

Pinker, R. T., Liu, H., Osborne, S. R., and Akoshile, C.: Radiative effects of aerosols in sub-Sahel Africa: Dust and biomass burning, J. Geophys. Res.-Atmos., 115, D15205, doi:10.1029/2009JD013335, 2010.

Pio, C. A., Legrand, M., Alves, C. A., Oliveira, T., Afonso, J., Caseiro, A., Puxbaum, H., Sanchez-Ochoa, A., and Gelencser, A.: Chemical composition of atmospheric aerosols during the 2003 summer intense forest fire period, Atmos. Environ., 42, 75307543, 2008.

Radojevic, M.: Chemistry of forest fires and regional haze with emphasis on Southeast Asia, Pure Appl. Geophys., 160, 157-187, 2003.

Sibold, J. S. and Veblen, T. T.: Relationships of subalpine forest fires in the Colorado Front Range with interannual and multidecadalscale climatic variation, J. Biogeogr., 33, 833-842, 2006.

Spracklen, D. V., Logan, J. A., Mickley, L. J., Park, R. J., Yevich, R., Westerling, A. L., and Jaffe, D. A.: Wildfires drive interannual variability of organic carbon aerosol in the western US in summer, Geophys. Res. Lett., 34, L16816, doi:10.1029/2007GL030037, 2007.

Sternbeck, J., Sjodin, A., and Andreasson, K.: Metal emissions from road traffic and the influence of resuspension - results from two tunnel studies, Atmos. Environ., 36, 4735-4744, 2002.

Streets, D. G., Yarber, K. F., Woo, J. H., and Carmichael, G. R.: Biomass burning in Asia: Annual and seasonal estimates and atmospheric emissions, Global Biogeochem. Cy., 17, 1099, doi:10.1029/2003GB002040, 2003.

Tesche, M., Ansmann, A., Muller, D., Althausen, D., Engelmann, R., Freudenthaler, V., and Gross, S.: Vertically resolved separation of dust and smoke over Cape Verde using multiwavelength Raman and polarization lidars during Saharan Mineral Dust Experiment 2008, J. Geophys. Res.-Atmos., 114, D13202, doi:10.1029/2009JD011862, 2009.
Thomaidis, N. S., Bakeas, E. B., and Siskos, P. A.: Characterization of lead, cadmium, arsenic and nickel in $\mathrm{PM}_{2.5}$ particles in the Athens atmosphere, Greece, Chemosphere, 52, 959-966, 2003.

Toth, J. J. and Johnson, R. H.: Summer Surface Flow Characteristics over Northeast Colorado, Mon. Weather Rev., 113, 1458-1469, 1985.

Vali, G., DeMott, P. J., Möhler, O., and Whale, T. F.: Technical Note: A proposal for ice nucleation terminology, Atmos. Chem. Phys., 15, 10263-10270, doi:10.5194/acp-15-10263-2015, 2015.

VanCuren, R. A.: Asian aerosols in North America: Extracting the chemical composition and mass concentration of the Asian continental aerosol plume from long-term aerosol records in the western United States, J. Geophys. Res.-Atmos., 108, 4623, doi:10.1029/2003JD003459, 2003.

Vaughan, M., Young, S., Winker, D., Powell, K., Omar, A., Liu, Z. Y., Hu, Y. X., and Hostetler, C.: Fully automated analysis of space-based lidar data: an overview of the CALIPSO retrieval algorithms and data products, Bba Lib., 5575, 16-30, 2004.

Watson, J. G., Fujita, E., Chow, J. C., Zielinska, B., Richards, L. W., Neff, W., and Dietrich, D.: Northern Front Range Air Quality Study Final Report, https://www.dri.edu/images/stories/ editors/eafeditor/Watsonetal1998NFRAQSFinal.pdf (last access: 16 September 2015), 1998.

Weber, B. L., Wuertz, D. B., and Welsh, D. C.: Quality Controls for Profiler Measurements of Winds and Rass Temperatures, J. Atmos. Ocean. Tech., 10, 452-464, 1993.

Westerling, A. L., Hidalgo, H. G., Cayan, D. R., and Swetnam, T. W.: Warming and earlier spring increase western US forest wildfire activity, Science, 313, 940-943, 2006.

White, A. B., Anderson, M. L., Dettinger, M. D., Ralph, F. M., Hinojosa, A., Cayan, D. R., Hartman, R. K., Reynolds, D. W., Johnson, L. E., Schneider, T. L., Cifelli, R., Toth, Z., Gutman, S. I., King, C. W., Gehrke, F., Johnston, P. E., Walls, C., Mann, D., Gottas, D. J., and Coleman, T.: A Twenty-First-Century California Observing Network for Monitoring Extreme Weather Events, J. Atmos. Ocean. Tech., 30, 1585-1603, 2013.

Wiedinmyer, C., Quayle, B., Geron, C., Belote, A., McKenzie, D., Zhang, X. Y., O'Neill, S., and Wynne, K. K.: Estimating emissions from fires in North America for air quality modeling, Atmos. Environ., 40, 3419-3432, 2006.

Winker, D. M., Vaughan, M. A., Omar, A., Hu, Y. X., Powell, K. A., Liu, Z. Y., Hunt, W. H., and Young, S. A.: Overview of the CALIPSO Mission and CALIOP Data Processing Algorithms, J. Atmos. Ocean. Tech., 26, 2310-2323, 2009.

Yamasoe, M. A., Artaxo, P., Miguel, A. H., and Allen, A. G.: Chemical composition of aerosol particles from direct emissions of vegetation fires in the Amazon Basin: water-soluble species and trace elements, Atmos. Environ., 34, 1641-1653, 2000.

Yang, Z. F., Wang, J., Ichoku, C., Hyer, E., and Zeng, J.: Mesoscale modeling and satellite observation of transport and mixing of smoke and dust particles over northern sub-Saharan African region, J. Geophys. Res.-Atmos., 118, 12139-12157, 2013.

Zamora, R. J., Dutton, E. G., Trainer, M., McKeen, S. A., Wilczak, J. M., and Hou, Y. T.: The accuracy of solar irradiance calculations used in mesoscale numerical weather prediction, Mon. Weather Rev., 133, 783-792, 2005. 